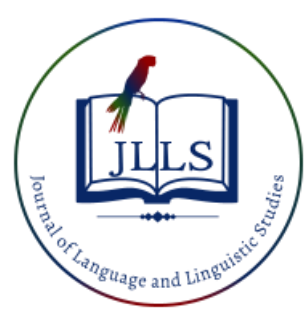

Available online at www.jlls.org

JOURNAL OF LANGUAGE

AND LINGUISTIC STUDIES

ISSN: 1305-578X

Journal of Language and Linguistic Studies, 17(1), 85-114; 2021

\title{
Equation of Malay vocabulary in the animation film of Upin and Ipin with
}

\author{
Banjarese vocabulary in South Kalimantan
}

\author{
Muhammad Rafiek ${ }^{\text {a } 1}$ iD \\ ${ }^{a}$ Lambung Mangkurat University, Banjarmasin, South Kalimantan, Indonesia
}

\section{APA Citation:}

Rafiek, M. (2021). Equation of Malay vocabulary in the animation film of Upin and Ipin with Banjarese vocabulary in South Kalimantan. Journal of Language and Linguistic Studies, 17(1), 85-114. Doi: 10.52462/jlls.6

Submission Date: 07/01/2021

Acceptance Date: 17/03/2021

\begin{abstract}
This research is aimed at explaining the equation of the Malay vocabulary in the animated film of Upin and Ipin with Banjarese vocabulary in South Kalimantan. In this research, the researcher used a qualitative method with comparative linguistic research design or equation characteristic method of linguistic features. In collecting the data, the researcher used the technique of listening and direct typing after watching the animated series Upin and Ipin on Youtube. In analyzing the data, the researcher used the equation techniques of forms and meanings of the vocabulary. This technique is called retention and innovation techniques together in methods of equation linguistic features (Mahsun, 2014). Researchers also analyzed and discussed using comparative linguistic theories from Adelaar, Blust, and Nothofer to reinforce the evidence that there are similarities in Malay vocabulary in the animated films Upin and Ipin with Malay vocabulary in South Kalimantan. The results of this research found that there are three groups of the equation of Malay vocabulary in the animated film of Upin and Ipin with Banjarese vocabulary in South Kalimantan, namely (1) Malay vocabulary in the animated film of Upin and Ipin have an equation in the form and differences meaning with the Banjarese vocabulary; (2) Malay vocabulary in the animated film of Upin and Ipin have an equation in form and meaning with the Banjarese vocabulary; and (3) Malay vocabulary in the animated film of Upin and Ipin have a semblance of forms and equation in meaning with Banjarese vocabulary, in South Kalimantan.
\end{abstract}

Keywords: equations; the difference; form; the meaning; vocabulary

\section{Introduction}

The animated film Upin and Ipin is the children's animated television series which was released on 14 September 2007 in Malaysia and broadcasted on TV 9. The series was produced by Les ' Copaque (https://id.wikipedia.org/wiki/Upin_\%26_Ipin). The animated film Upin \& Ipin broadcasted on MNCTV Indonesia. Based on the observations of the researcher through watching and listening to the character's utterances in the animated film Upin and Ipin there is some equation between the vocabulary of Malay and Banjarese vocabulary. Some of these equations could be seen from the use of the word abah which means father, sunat means khitan and others. Because the research frequently

\footnotetext{
1 Corresponding author.

E-mail address: mrfk@ulm.ac.id
} 
watching and listening to the equations vocabulary that is spoken by the character, so the researcher is interested in doing this research.

The research of the equation of Malay vocabulary in the animation film of Upin and Ipin with Banjarese vocabulary in south Kalimantan has never been done by others. Earlier studies of the animated film Upin and Ipin were not related to the similarities of vocabulary but other topics. Research on animation film of Upin and Ipin were ever done by Saputro (2011), Arlena \& Kurniasari (2013), Rusieshvili-Cartledge \& Gözpınar (2014), Aitkuzhinova-Arslan, Gün, \& Üstünel (2016), Akbulut (2017), and Aziz, Yusuf, Nasir, \& Masyithah (2017). Saputro (2011) in his research entitled Upin \& Ipin: Melayu Islam, Politik Kultur, dan Dekomodifikasi New Media found that animated Upin and Ipin represent the idea of a Unity of Malaysia (one Malaysia) in its cultural and ethnic differences. Saputro discusses the Pengembaraan Bermula, the demographic Durian Runtuh, ethnic diversity, Harmony Raya, daily practice and thinking, the subject of the parody, the subject of domination, diversity reason and cover: meneroka politics (and) animation. Arlena \& Kurniasari (2013) in their research, entitled Malays, China, and Indian Ethnicities (Case Study: Art and Ethnography Content Analysis, Multiculturalism on Upin Ipin Animation) found that in the movie, there is a picture of good relationship in different intercultural such as Malay, China, and India.

Rusieshvili-Cartledge \& Gözpınar (2014) has researched on Similar and unique in the family: How to raise children (Using examples of Turkish and Georgian proverbs relating to children). In their research, it was found that the similarities and differences between the cultures in Turkish and Georgian proverbs. Rusieshvili-Cartledge \& Gözpınar research (2014) used the study of semantic models.

Aitkuzhinova-Arslan, Gün, \& Üstünel (2016) has researched Teaching vocabulary to Turkish young learners in semantically related and semantically unrelated sets by using digital storytelling. The result of their study was that young learners developed vocabulary results both at SR and SUR tests at the end of the vocabulary studying process. The Aitkuzhinova-Arslan, Gün, \& Üstünel (2016) study also refers to Piaget's theory of cognitive development.

Akbulut (2017) examined the effects of morphological awareness on second language vocabulary knowledge. In his study, Akbulut (2017) found that participants studied with morphological treatment were seen in morpheme-morpheme items and more vocabularies than others using traditional vocabulary teaching procedures. Akbulut's research (2017) also found that morphological awareness tasks can contribute to vocabulary teaching and can be placed in the Pedagogy and English teaching curriculum.

Aziz, Yusuf, Nasir, \& Masyithah (2017) in their research, entitled Cross-Linguistic Influences of Malay Through Cartoons on Indonesian Children's Language Use in the Home Domain found a loan or loans, the influence of phonetic, infix, interjection, and intonation in the film of Upin \& Ipin, Boboboi, and Pada Zaman Dahulu. In the research, they discussed akak (sister), padan muke, and seronok. Especially different seronok meanings between Malay and Indonesian. Under the influence of Phonetics, they discussed apalagi, suka, Kita which are spoken by Malay as apelagi, suke, and kite. They also discussed about la [la], ni [ni], and ke [kə] in Malay with lah [lah], ini [ini] or nih [nih], dan $k a h$ [kah]. Also, they discuss interjection ish ish ish and Amboy in Upin and Ipin. The research of Aziz, Yusuf, Nasir, \& Masyithah (2017) only examined the problem of the vocabulary of Malay with the Indonesia in General. Their research did not compare the vocabulary of Malay with Banjarese. Therefore, this research becomes very important to find more deeply the equation of the Malay vocabulary in the animation film of Upin and Ipin with Banjarese vocabulary in South Kalimantan. 


\subsection{Literature Review}

Based on previous studies, research of the equation of Malay vocabulary in the animation film of Upin and Ipin with Banjarese in south Kalimantan has never been done by researchers. Therefore, this research becomes early research about the equation of Malay vocabulary in the animation film of Upin and Ipin with Banjarese in South Kalimantan. de Hollander (1984, p. 228) stated that the Malay vocabulary or Arabic Malay are the branches of the language family that cover most of the archipelago. According to de Hollander (1984, p.228), the equation with other languages in the language family is not only in vocabulary but also in the way of forming words and the whole building of language. Based on the explanation of de Hollander, Malay languages in the archipelago have an equation in vocabulary, grammar, and all parts of the language.

Marsden and Werndly (de Holländer, 1984, p.243) distinguish two vernaculars, namely (1) the dialect spoken in the Semenanjung Melayu beaches (Kedah, Melaka, Johor, Pahang, Trengganu, Kelantan, Patani and (2) the dialect spoken in the ancient kingdom of Minangkabau (now Daratan Tinggi Padang, West Sumatra) as well as in the Malay settlements along the coast of Sumatra and the Semenanjung Melayu hinterland as well. de Hollander (1984, p.243) stated that Malay purely consists of two vernaculars, namely Malaka (Malay) or Riau and Minangkabau or Padang vernacular. van Wijk (1985, p. XVIII) stated that Malay is the language spoken by the inhabitants of Central Sumatra from the East Coast to the West Coast, the peninsula Malaka (Malaya) with two islands located in the South and the Malay settlements on the West of Kalimantan coast. The opinion from van Wijk leads more to the spread of the Malay to Kalimantan. van Wijk (1985, p. XVIII) stated that Malay is made up of the Malay language of West Sumatra (Minangkabau language) and Johor language or Riau. van Wijk (1985, p. XVIII) also described the spread of Malay throughout the islands of the East Indies. Cense \& Uhlenbeck (1958, p.9) mentioned that the Banjarese is one of the Malay dialects in Kalimantan island.

The view of van Wijk, Cense, and Uhlenbeck were opposed by Kawi (2011, p.195) who stated that the exploration of Banjarese people through the beach and sea is not only limited to the direction of the Western region of Indonesia like Sumatra and Malaysia but also the eastern region such as Nusa Tenggara, Sulawesi, and Maluku. The statement of Kawi showed that the arrival of Banjarese language in Malaysia because it is carried by a sailor of Banjar in ancient times. Kawi (2011, p.199) also stated that the merchants of Banjar do trade transactions with European in Singapore. It also showed that through trade routes, the Banjarese language comes up to Singapore. Saleh (in Kawi, 2011, p.137) stated that ships or boats that sailed over Indonesia and come to Siam. Kawi (2011, p.199) reaffirms that the Banjarese people create places of a stop-over in Malaysia such as Johor, Perak, Selangor, and Singapore.

Kawi (2011, p.199) also informed about the occurrence of the massive migration of Banjarese people into Sumatra and Malaysia in relatively large amounts in the 19th century. Kawi explained that after years of 1868, the Netherlands walked along and arrested the servants of the Penghulu Rashid. People of Kelua (Banjar) performs the initial migration outside the region in order to save themselves from the Netherlands Army pursuit heading to Sumatra and Malaysia (Kawi, 2011, pp.199-200). Kawi (2011, p.200) also explained the events after "Amuk Hantarukung" at Kandangan in 1898, some Kandangan and Barabai people try to save themselves by migrating to Sumatra and Malaysia. Apart from the two opposite views, Blust (1988) through his reconstruction diagram shows that the Malay vocabulary in Malaysia and Banjarese language in South Kalimantan is the language. Adelaar (1985) also said that the Malay language and Banjarese are isolect proto of Malay. Previously Adelaar (1984, p.403) also stated that the Malay vocabulary and Banjarese language are Malay dialects. Therefore, there are few similarities between the vocabulary of these languages.

The existence of the Banjarese language speakers in Malaysia was also known from Rafiek (2010) in his paper entitled Masa Depan Bahasa Banjar. In his paper, Rafiek (2010, p.1) based on 
information from Hapip, Kawi, \& Noor (1981, p.7) explains that the Banjarese language is also used and developed until the land of the peninsula (Malaysia). Regardless of the existence of the Banjarese language speakers in Malaysia, the researcher still refers to the view of Blust and Adelaar above stating that the Banjarese and Malay language is the grouping language. Cense \& Uhlenbeck (1958, p.9) stated that the Banjarese language is spoken in Banjarmasin and its surrounding and also in Hulu Sungai. Cense \& Uhlenbeck (1958, p.9) also informed that the Banjarese language is spoken in Kutai and Pasir and refers to Den Hamer, it is also spoken on the Pulau Laut and Sampit. Den Hamer (Cense \& Uhlenbeck, 1958, p.9) distinguished among the local dialects in Amuntai and Alabio, Klua, Tanjung, and Kandangan. Den Hamer (Cense \& Uhlenbeck, 1958, p.9) also believed that the language spoken by the people of the hill became a dialect of Banjar.

Hapip, Kawi, \& Noor (1981, p.8) stated that the Banjarese language is widespread along the coast of South and East of Kalimantan, thrive far into the upper course of the river Barito especially and its tributaries, even up to places on the island of Sumatra and the land of the peninsula (Malaysia). Hapip, Kawi, \& Noor (1981, p.8) also stated that the Banjarese language has two dialects, namely the hulu dialect and kuala dialect. Banjarese language speakers of hulu dialect are found in Tapin Regency, Hulu Sungai Selatan Regency, Hulu Sungai Tengah Regency, Hulu Sungai Utara Regency, Tabalong Regency, and the Balangan Regency. Speakers of Banjar kuala dialects are in the city of Banjarmasin, Banjarbaru, Banjar Regency, Tanah Laut Regency, Kota Baru Regency, Barito Kuala Regency and the Tanah Bumbu Regency. Durasid \& Kawi (1978, p.1) stated the Banjarese language consists of two dialects, namely kuala and hulu dialects. Durasid \& Kawi (1978, p.1) confirmed that the speakers of hulu dialects are in Tapin Regency, Hulu Sungai Selatan, Hulu Sungai Tengah, Hulu Sungai Utara, and Tabalong. Kawi (2002, p.151 and 170) divided the Banjarese language into three dialects, namely the kuala dialect, hulu dialect, and hill dialect. This proves the statement Den Hamer said that the language spoken by the people of the Hill is a dialect of Banjar.

Keraf (1991, p.33) stated that the equation of forms owned by a language will be more convincing again if the forms showed also semantic similarities. The theory used in this research is the theory of the universal language, i.e. similarities in form and meaning (Keraf, 1991, p.33). Besides, the universal language theories also state that each language has the smallest functional unit of the device, i.e. the phoneme and morpheme. Universal language theories also contain that every language in the world has specific word classes, namely nouns, verbs, adjectives, pronouns, numerals, and words (Keraf, 1991, p.33). Keraf (1991, p.34) stated that the languages of the relatives which came from the same proto-language always will show similarities such as (a) equation system of sound (phonetic) and formation of sound (phonological) and (b) morphological equation, namely the similarities in the form of words. Linguistic comparison studies the similarities of form-meaning as a result of the development of a proto (Keraf, 1991, p.36). Keraf (1991, p.36) concluded that a semblance of formmeaning in languages is caused by three factors, namely (1) because the inheritance directly by two languages or more than one of the same proto, (2) due to coincidence, and (3) because of the loan.

\section{Research Methods}

The method used in this research was qualitative descriptive methods. The qualitative descriptive method used to describe and explain the equation of the Malay vocabulary in the animated film of Upin and Ipin with Banjarese vocabulary in South Kalimantan. The qualitative descriptive method tries to describe the parallels or similarities of two languages with vocabulary explanations based on the dictionary, knowledge, and experience of researchers, and information by informants. Qualitative descriptive methods referred to in this section are a method in common linguistic traits (Mahsun, 2014, p.76). Mahsun (2014, p.76) stated that the method of similarities linguistic traits can be used for the determination of kinship and grouping of dialects/subdialect and qualitative language. Mahsun (2014, 
p.51) stated semblance of linguistic traits can be semblance in maintaining the elements of ancient languages and similarities in performing the renewal (shared innovation). Further, Mahsun (2014, p.76) stated that there are two traits in a common form of linguistic kinship determination of language, namely retention and shared innovation. In this case, the researcher used retention and shared innovation.

A retention is a group of user language areas that together still maintain the ancient language sound or proto (Mahsun, 2014, p.52). Shared innovation is the shared language that performs updates (innovation). Mahsun (2014, p.77) stated the method of innovation along with more responsive, even if the language is comparable (which showed innovation with it) it is located far apart. It will prove that in common innovation exclusively is not as a result of a loan or influences affect each other. In this study, the researcher studied the semblance of the Malay vocabulary in an animation film of Upin and Ipin with Banjarese vocabulay in the province of South Kalimantan, Indonesia.

The data source is an animated film of Upin and Ipin entilted Musim Pertama in 2007, Ambil Galah, Tolong Tunjukkan season 3 in 2009, Seronoknya Membaca in 2009, Juara Kampung season 4 in 2010, Ramadhan Kembali Lagi season 4 in 2010, Sakit Ke? season 5 in 2011, Terbang TinggiTinggi season 5 in 2011, Garang ke Sayang season 5 in 2011, Jari-Jemari Salleh season 5 in 2011, Kembara Kecil-Kecilan season 6 in 2012, Kenangan Mengusik Jiwa season 6 in tahun 2012, Beli, Pakai, Suka season 7 in 2013, Gigi Susu season 7 in 2013, Riang Raya season 7 in 2013, Pokok Seribu Guna season 8 in 2014, Belajar sambil Main season 8 in 2014, Hasil Tempatan season 8 in 2014, Dah Bocor season 9 in 2015, Dulu dan Sekarang season 9 in 2015, Kedai Makan Upin dan Ipin season 9 in 2015, Siapa Atan? season 9 in 2015, Patuk Kau season 10 in 2016, Bila Cuti Sekolah season 10 in 2016, Ragam Rayaseason 11 in 2017, Di Sebalik Tabir in 2017, Mainan Baru season 11 in 2017, Kembara 6 Musim in 2017, Terlajak Laris in 2017, Masih Ada Sayang in 2017, Teroka Lautan in 2017, and Masak-Masak in 2018. The data used in this research is every semblance speech is the character in the animated series Upin and Ipin of Malay vocabulary has equation of the in form and meaning with the Banjarese vocabulary. Data collection techniques was done by watching, listening, and typing directly every speech of the character in the animated series Upin and Ipin which contained Banjarese vocabulary that has semblance of form and meaning with Malay vocabulary.

\section{Results}

3.1 Equation of Malay vocabulary in the animation film of upin and ipin with banjarese vocabulary in south Kalimantan

\subsubsection{Simbah}

In the animation series of Upin and Ipin titled Musim Pertama Episod 1 Esok Puasa in 2007 there is simbah word spoken by Kak Ros. Kak Ros says Ih budak-budak ni ... Aka simbah ya (se) karang (Ich this children .... I flush you are now).. Simbah word in the Malay vocabulary has equation and difference form and meaning with the word simbah in Banjarese vocabulary. Simbah word in Malay means siram or percik. The word simbah in Banjarese means jauhkan or sibak (Hapip, 2008, p.170). Word that means siram or percik in Banjar is cipui or lapai. Lapai means percik air (Hapip, 2008, p.105). Cipui means percik air. For siram word, Banjarese vocabulary keeps using the word siram and simbur in daily communication interchangeably, for example, manyiram kambang (watering flowers) or manyimbur kucing bakalahi (watering catfighting).

\subsubsection{Basuh}

In the animation series of Upin and Ipin titled Garang ke Sayang part 2 in 2011, there is basuh word spoken Cikgu Besar. Cikgu Besar said Is is is sudah berapa bulan tak basuh? Kotor Sangat nih (how many months do not wash? So dirty). Cikgu Besar said it was after seeing shoes Upin and Ipin 
are dirty because it has not been washed. Basuh in Malay has an equation in meaning and form with the word basuh in Banjarese vocabulary. Basuh in Malay and Banjarese have the same meaning, namely cuci. Upin and Ipin originally mistook Cikgu Jasmin will go to their classes, it turns out that goes is Cekgu Besar. In Banjarese, the word basuh is used to basuh tangan wan batis (washing hands and feet), basuh the genitals (washing genital), basuh burit (washing the anus or buttocks), basuh kendaraan (washing motor bikes), and basuh muha (washing face). Sometimes the sound also inya bahera kada babasuh (he defecate and does not wash or cleaned). In the animation series of Upin and Ipin titled Garang ke Sayang part 2 in 2011, there is basuh word spoken by Kak Ros and Ipin. Kak Ros said Pergi basuh tangan sampai bersih, lepas tu basuh kasut (washing your hand, after that wash the shoes). Ipin said Ye dah siap basuh (Ye ready to wash). Basuh in Malay word has an equation in meaning and form with the word basuh in Banjarese vocabulary. Basuh spoken by Kak Ros in Ipin in Malay has the same meaning in Banjarese, namely cuci. The word basuh in the Banjarese vocabulary is related to washing the feet, hands, face, ass, and mouth. The word basuh in the Banjarese vocabulary is also related to washing cups, saucers, spoons, and cutlery and cookware, and other kitchens.

\subsubsection{Sorang}

In the animation series of Upin and Ipin titled Muslim Pertama Episod 4 Terawih in 2007, there is sorang word spoken by Fizi. Fizi said Hahaha aku main sorang (Hahaha I play by myself). Sorang word in Malay has an equation in form and the meaning with Banjarese. Sorang in Malay and Banjarese meanssendiri. Fizi said sorang after he no longer pursued by Ehsan in- romp game. In the animation series of Upin and Ipin titled Juara Kampung part 1 in 2010, there is a sorang word spoken by an Upin. Upin said Sorang je, mana Ehsan? (Alone, where Ehsan?). Sorang in Malay has an equation of the form and the meaning of with Banjarese. Sorang in Malay and Banjarese means sendiri. In Banjarese, there is sorangan word which means sendirian. The use of the sorangan word can be read in the sentence aku sorangan haja semalam ke wadah sidin (I was alone going to him yesterday). In Banjarese vocabulary, the sorang word could be used jar sorang, baingat makan Kena Sakit parut (I said, don't overeat it will cause abdominal pain). Sorang in Banjarese can be interpreted as saya. Another example, sorang jua dulu nang manolonginya (i used to help him). In Banjarese, sorang can be also spelt saurang.

\subsubsection{Hentam or Hantam}

In the animation series of Upin and Ipin titled Musim Pertama Episod 4 Terawih in 2007 there is a hentam word said by Upin. Upin said Teruk kita orang kena hentamdengan Kak Ros semalam tu (Seriously we got hentam by Kak Ros yesterday night). Hentam (hantam) word in Malay has equation in form and meaning with hantam in Banjarese. Hentam (hantam) in Malay and Banjarese mean pukul dengan genggaman atau kepalan tangan. In present Upin holding or touching part of his face that hit by Kak Ros. So, hentam word here means pukul (memukul) di pipi. In other words, hentam means menepuk di pipi. Hentam (hantam) is usually used in the Banjarese vocabulary to pronounce or say something related to a fight using hand by men. Now, hentam (hantam) means widely, it could be mean memukul dengan menggunakan benda keras dan tumpul. The use of hamtam words in Banjarese vocabulary for example kuhantam kena muhanya tu (I hit in his face), hantam jakanya urang nang kaya itu tu, nyaman tahu rasa (i want to hit people like that, he deserve it), kelo kuhantam nyawa, nyaman jara (want to get hit by me? U deserve it), hantamkah? (want to get hit by me?), mambari muar saikung ni, kuhantam kena (you are so annoying, i will hit you), mun kada dihantam kada jara saikung ni (if i dont hit him. He not cured of his habbit), ada kena wayahnya inya ni dihantam urang, hanyar tahu (there is time, he will know the feeling of getting beat by someone), ayu ja karasi nyaman kuhantam (if you still stubborn, i will hit you). 


\subsubsection{Semalam}

In the animation series of Upin and Ipin titled Musim Pertama Episod 4 Terawih in 2007, there is a semalam word pronounced by Upin. Upin said Teruk Kita orang Kena hentamdengan Kak Ros semalam tu (Seriously, we got hit by Kak Ros yesterday night). Ha ... Lepas semalam tu kita orang dah tak main, dah kita orang sembahyang betul-betul (Ha ... after yesterday, we didnot play any more, just praying seriously). Semalam word in Malay vocabulary has an equation in form and meaning with semalam Banjarese vocabulary. Semalam in Malay and Banjarese vocabulary have the same meaning, that is kemarin Malam (last night). In the animation series of Upin and Ipin titled Seronoknya Membaca part 1 in 2009 there is semalam word spoken by Cikgu Jasmin. Rather, the Cikgu Jasmin asked Murid-murid dah baca buku cerita yang cikgu bagi semalam? (have you already read the storybook yesterday?). Semalam word in Malay vocabulary has an equation in form and meaning with Banjarese vocabulary. Semalam in Malay and Banjarese mean yesterday. Semalam means waktu telah lewat satu malam. Therefore, to mention the last day used semalam. Cikgu Jasmin uses the word semalam concerning ask if the pupils have read storybooks distributed semalam (last night).

\subsubsection{Ma ... Abah}

In the animation series of Upin and Ipin titled Musim Pertama Episod 6 Hari Raya in 2007 there is abah word that pronounced by Upin. Upin ask Opah, Opah, Opah, Ma ngan Abah dulu puasa tak?(Grandma, Grandma, are mother and father fasting or not?). Then Opah replied He...empuasa (ya, fasting). Upin said Uui banyaklah pahala ma ngan abah (Uui, there are much reward to them). According to $m a$...abah word in Malay has an equation in form and meaning with $m a$...abah word in Banjarese vocabulary. Ma ...abah word means $b u$ (mother) and the dad. $M a$ is constructed by the syllables of the words mama. Abah could be translated to Bapak, father. Ma and abah word pronounced by Upin when they visit the grave of their parents. Abah means bapak in kamus MelayuIndonesia compiled by Ikram, Saleh, Mutiara, Augusdin, \& Rukmi (1985, p.1).

\subsubsection{Kerangge or Kerangga}

In the animation series of Upin and Ipin titled Ambil Galah, Tolong Tunjukkan season 3 in 2009 part 2 contained the word kerangge or kerangga spoken by the Jarjit, Mail, and Ehsan. Jarjit said Aduh duh duh duh aduh aduh aduh banyak kerangge aduh sakit sakit sakit. Mail says Tak naklah,kan banyak kerangge, tunggu Atok ajalah (i dont want, there are a lot of the red ants, just wait Atok). Ehsan said Kerangge banyak, kasihan Jarjit kena gigit (there are a lot of red ants, poor Jarjit who bites by them). In the animation series, kerangge or kerangga is present in the rambutan tree. The word kerangge or kerangga in the Malay vocabulary has equation in form and meaning with the word kerangga in Banjarese vocabulary. Kerangge or kerangga in Malay and Banjarese meaning semut hitam yang ada di pohon buah. Kerangge or kerangga usually inhabited in sweet fruit trees. Kerangge or kerangga bites can cause pain and itching on the skin. To eliminate the pain and itchy bite marks by kerangge used oil. Banjarese usually call kerangge with samut karangga.

\subsubsection{Putik}

In the animation series of Upin and Ipin titled Bila Cuti Sekolah part 3 in 2016 there is putik word spoken by Mail. Mail said Kau orang boleh aku putik buah-buah cermai ni (You guys could I pick this cermai fruit). Putik in Malay has an equation in meaning and form with putik in Banjarese vocabulary. Putik in Malay and Banjarese has the same meaning, namely petik or ambil. Mail picked cermai fruit that fell under the tree cermai. Then he borrowed a toy truck belonging to Mei Mei for transporting the collected cermai and bring to his home. In the animation series of Upin and Ipin titled Terlajak Laris part 1 in 2017, there is putik word spoken by Ipin. Ipin said Betul...betul...betul...kita orang yang tolong Atok putik tadi (Correct ... correct ... correct ... we help Atok to pick it). Ipin explained to Mail and Fizi that he is the one who helped Atok to pick that maggo. Putik in Malay has an equation of 
meaning and form with putik in Banjarese vocabulary. Putik in Malay and Banjareseis equally meaningful petik. Putik in Banjarese can be used to pick fruit, vegetable, chili, including clothes in a clothesline. Related to take the clothes in the clothesline, there is a sentence putiki tapasan di jamuran, hari handak hujan (Lift or grab the laundry (clothes) on the clothesline, it will be raining).

\subsubsection{Penat}

In the animation series of Upin and Ipin titled Terbang Tinggi-Tinggi part 2 in 2011 there is penat word spoken by Tok Dalang Upin. Tok Dalang said Memanglah, penat nanti, senyaplah tu (Surely, after tired, would be silence). Upin said I burung diamlah, Kau ni tak penat (please, shut up, it would be tired). The word penat in Malay has a semblance of form and meaning with panat in Banjarese vocabulary. Penat here (in Malay vocabulary) also means the same as panat in Banjarese vocabulary just change vowel e to be a. Penat word used by Tok Dalang and Upin to comment on votes the Magpies. Tok Dalang told Upin if the Magpies continued to say later it will be exhausted too. In the animation series of Upin and Ipin titled Garang ke Sayang part 1 in 2011, there is penat word spoken by Ipin. Ipin said Penat Ipin (tired Ipin). Ipin said penat because he joined Upin to chase tokdalang who riding his motorcycle to the garden. The word penat in Malay has a semblance of form and meaning with panat in Banjarese vocabulary. The word penat in Malay is pronounced panat in Banjarese vocabulary. The word penat in Malay and panat in Banjarese vocabulary have the same meaning, namely, Capek ot lelah. Ipin feels fatigued after running the Tok Dalang chase riding a motorcycle to the garden.

\subsubsection{Dodol}

In the animation series of Upin and Ipin titled Ramadhan Kembali Lagi part 4 in 2010 there is dodol word spoken by Tok Dalang dan Upin. Tok Dalang said Atok ingat nak buat dodol tahun ni (Atok remember wanted to make dodol this year). Upin asked Abang Badrus suka dodol ya Tok?. Tok Dalang said Oi inilah kegemaran dia masa raya, Kalau Dodol durian, lagi gila. Dodol in Malay has equation in meaning and form with dodol in Banjarese vocabulary. Dodol means adonan tepung ketan ditambah gula merah dan santan yang dimasak di kawah besar dan setelah masak lalu dibentuk sesuai keinginan atau selera. Dodol could be eating after cold and harden. In the animation series of Upin and Ipin titled Ramadhan Kembali Lagi part 4 in 2010 there is dodol word spoken by Upin. Upin said Isukkan nak buat dodol? (do we make dodol tomorrow?) Upin reminded Ipin because Kak Ros will take him to market the next day. Yet Upin and Ipin will make dodol the next day. Dodol in Malay has equation in meaning and form with the dodol in Banjarese vocabulary. Dodol means cookie from dough of sticky rice, sugar, and coconut milk. All of the dough is stirred so one inside the crater (crock). After cooking, dough dodol is made of various shapes according to the wishes or tastes. Dodol could be eating when it's cool and harden.

\subsubsection{Parut}

In the animation series of Upin and Ipin titled Ramadhan Kembali Lagi part 4 in 2010 there is parut word spoken by the Tok Dalang. Tok Dalang Lepas ni, kita parut kelapa (After ni, we shaved the coconut). Parut in Malay vocabulary has an equation of form and meaning with parut in Banjarese vocabulary. There is the same meaning, that is serut. Parut in Banjarese vocabulary could be means perut depending on the context of the sentence. In Banjarese, there are sentences pamali habis Makan langsung mandi Kena parut baganal (beware, don't do bat after eating, that would make the stomach bigger). In Banjarese there is the word paparutan which means usus atau isi perut, e.g. takaluar jar paparutannya (out his intestines or stomach contents). The word paparutan can be also linked with paparutan ayam (chicken intestine or stomach contents) or paparutan iwak (bowel or stomach contents of fish). Coconut meat or dried palm rasped (planed) using parutan or parodan (sharp serrated zinc made it to planed which is usually used with one hand holding the parodan and another 
handheld palm to planed up and down). Besides, dried coconut meat planed by using the rasped engine as used by Tok Dalang. Based on the experiences and observations of the researcher on childhood time to market, the machine grated coconut is used by inserting the peeled coconut meat and skin deep cleaned while pressing to rasped tool carefully. Coconut rasped machine used by Tok Dalang already looks good because dried coconut meat just rubbed or suppressed to the rasped tool that rotates so it's no danger for hand. Rasped machine-dried coconut meat belonging to the Tok Dalang made of motorcycles with parts of the head is a rasped machine.

\subsubsection{Laju}

In the animation series of Upin and Ipin titled Ramadhan Kembali Lagi part 4 in 2010 there is laju word spoken by Upin and Tok Dalang. Upin said Atok, laju lagi Tok (Atok, more speed Tok). Tok Dalang then said Laju lagi, boleh (faster again, it could). Upin replied by saying Lajunya (so fast). The word laju in Malay vocabulary has the equation of form and meaning to the word laju in Banjarese. It has the same meaning, that is cepat (fastly). Upin said laju for requesting Tok Dalang to speed rasped dry coconut meat machine. Tok Dalang who hears immediately accelerate the speed of the rasped engine that has been modified from the bike which vibrating. It makes Upin said lajunya (it so fast). Tok Dalang, Upin, and Ipin use a helmet when using the rasped dry coconut meat machine motorcycle that has been modified. It would cover the face and eyes from the spark of the hard shell which shave in the rasped machine.

\subsubsection{Isuk}

In the animation series of Upin and Ipin titled Ramadhan Kembali Lagi part 4 in 2010 there is isuk word spoken by Ipin, Kak Ros, and Upin. Ipin said Isuk buka apa kak? (tomorrow, what should we eat for ending the fasting?). Kak Ros said Isuk ikut aka pergi ke pasar (let's going to market tomorrow). Upin said Isukkan nak buat dodol (tomorrow want to make dodol). Isuk in Malay has an equation in meaning and form with the word isuk in Banjarese vocabulary. Isuk means tomorrow. In Banjarese, there is also the use of isuk word with affix such as baisukan which means morning. The sentence is baisukan ja kena kita panderakan (just talked about in the morning). In the animation series of Upin and Ipin titled Jari-Jemari Salleh part 3 in 2011 there is isuk spoken by Upin. Upin said isuk Kita nak ke rumah abang Salleh (tomorrow we wanted to go Salleh's home). Upin said this because asked by Susanti. Susanti asked Eh besok kamu ngapain? Isuk in Malay has an equation in meaning and form with the word isuk in Banjarese vocabulary. Isuk words in Malay and Banjarese have the same meaning, namely esok or besok. In Banjar there are sentences Baisukan isuk inya turun sakulah (the next tomorrow morning he goes to school). Other sentences Isuk inya handak peleseran (tomorrow he wanted to look around).

\subsubsection{Kawah}

In the animation series of Upin and Ipin titled Ramadhan Kembali Lagi part 5 in 2010 there is kawah word spoken by Tok Dalang and Upin. Tok Dalang said Tolong Atok angkat kawah tu (Take the big wok, please). Upin asked Kawah, kawah tu apa Tok? (wok? What is wok Atu?). Then Tok Dalang said kuali besar tu. Kawah in Malay and Banjarese vocabulary has the same meaning and form. It means kuali besar. Hapip (2008, p.86) stated kawah is kuali besar. Based on research observations, kawah was used to cook the beef rendang for the celebration of marriages. Strips of beef are put into kawah that contains water. After the beef is cooked or tender then put spices or herbs including sugar and shavings of dried coconut meat into it. Stir in beef dishes in the crater using drivers (such as paddle sampan or boat). People work together cooking the beef in the kawah. In the animation series of Upin and Ipin titled Ragam Raya part 1 in 2017 there is kawah word spoken by the Tok Dalang. Tok Dalang said gulai kawah. Kawah in Malay has an equation in meaning and form with the kawah word in Banjarese vocabulary. Kawah in Malay and Banjarese means kuali besar atau 
wajan besar yang digunakan untuk memasak nasi atau daging. Kawah used to cook large amounts of food is usually for food or to celebrate festivals or marriage. Kawah is placed on top of the firewood that has been given a pedestal in the yard usually for easier stirring people's cuisine. Now, to its fuel can already use gas. Cooking in kawah using a form of stirrer paddle or rower.

\subsubsection{Kacau}

In the animation series of Upin and Ipin titled Ramadhan Kembali Lagi part 5 in 2010 there is kacau word spoken by Tok Dalang, Salleh, Upin and Ipin. Tok Dalang says E...Nak buat dodol kena sabar, nak kacau, nak jaga api, nak masak pun lama (E. .. Want to make dodol have to wait, be patient, keep the fire, and need long time to cook it). Salleh said baik-baik sikit kacau tu, jatuh nanti, kau yang jadi dodol (stir well, if fell later, you're being dodol). Upin and Ipin said Meletuplah ... macam mana nak kacau ni? (exploded) ... How come to stir?). Kacau in Malay vocabulary has an equation of form and meaning with Banjarese vocabulary. Kacau in Malay and Banjarese means aduk. This was confirmed by Hapip (2008, p.73) stating that kacau means aduk. In the animated film Upin and Ipin, Upin and Ipin are stirring dodol in the crater using paddle canoes or boats. Upin and Ipin stirring dodol dough in the crater while singing Dayung-dayung sampan, .... dayung jauh-jauh.

\subsubsection{Sunat}

In the animation series of Upin and Ipin the titled Sakit Ke? Part 1 in 2011 there is sunat (khitan) word spoken by Ehsan, Fizi, Upin, Ipin, Mei Mei, Mail, Ehsan, Fizi, Upin, and Ipin, said Sunat? (Khitan?). Mei Mei asked sunat tu apa? (what is Khitan?). Mail said Sunat tu, dia potong aku punya (Khitan is he cut I had). Fizi said Habislah kau orang, bapakku kata sunat ni sakit (Poor you, my daddy said Khitan is pain). Mail replied pasal sunat (about Khitan). Mail continued Kita orang Cerita pasal sunatlah (we have stories about Khitan). Ehsan said Aku tak nak sunat (i dont want to khitan). The word sunat in Malay vocabulary has an equation of form and meaning of sunat in Banjarese vocabulary. Sunat in Malay and Banjarese means khitan. Thus, besunat means berkhitan. Sunat is the cutting off of the foreskin of a male penis. Sunat will be penis head is clearly visible. Sunat started with injecting the drug into the penis so that when cut skin cover is not painful. When injected, the skin that covers the penis is pulled forward to cut. The leather cover is the back part of the penis that is left of the former cut bandaged with gauze or cloth Kassa after first sprinkled the drug. After the closing of the skin of the penis is cut then stitched around the penis so that the skin does not close the cover again. Now, there's the technique of sunat with klamp. Cloth pads sunat already opened or removed after a week or ten days. At the time to detachable penis part, bandaged up soaked in water for a few hours to make it easier to release. Usually the children who need to remove the bandage sunat, soak in a tub that has filled the air.

\subsubsection{Buluh}

In the animation series of Upin and Ipin titled Terbang Tinggi-Tinggi part 1 in 2011 there is buluh spoken by Tok Dalang, Upin, and Mail. Tok Dalang said Nasib baik ada buluh lagi, lepas tu ikat dengan buluh $n i$ (good luck there are bamboo again, after that belt with this bamboo), and Habislah buluh aku (my bamboo is over). Upin said Banyaknya buluh, nak buat apa ni Tok (Tuk)? (a lot of bamboos, want to create something Tok?). Mail said Tok nak buluh lagi Tok (i want to more bamboo Tok). Buluh in Malay vocabulary has an equation of form and meaning with buluh in Banjarese. It means Bambu or pering. Pering in Banjarese vocabulary is spoken to paring. Pering is derived from Javanese Bambu. Pering pronounced pring in ngoko levels and dealing on the level of kromo (Mangunsuwito, 2009, p.480). Buluh in the animated film of Upin and Ipin are used as basic materials to make kites. Buluh is thinly sliced and smooth less can be used as the basic framework of the kite. The kite frame made of two strips of crossed buluh is then tied with thread. 


\subsubsection{Burung Bubut}

In the animation series of Upin and Ipin titled Terbang Tinggi-Tinggi part 2 in 2011 there is burung bubut spoken by Tok Dalang. Tok Dalang said Kau orang tahu burung bubut?Burung bubut in the Malay vocabulary has equation of form and meaning to the word burung bubut in the Banjarese vocabulary. Burung bubut in Malay and Banjarese means burung besar yang terbang di dekat persawahan atau ladang atau pepohonan yang bisa dibuat minyak sapu (sapuan) atau oles (olesan) untuk luka, patah, dan lain-lain (big birds that fly near of rice fields, or fields, or trees can be made into oil for cut, fracture etc). The ointment according to Tok Dalang was made from the broken birds lathe's feet and let it after fixed, then boiled up the birds to get of the oil. In Kamus Banjar-Indonesia by Hapip (2008, p.19), burung bubut is the name of a type of bird-eating caterpillars. Hapip (2008, p.19) also give a description of the minyakbubut, namely oil from birds lathe (which is effective for healing broken bones or sprains).

\subsubsection{Buruk}

In the animation series of Upin and Ipin titled Garang ke Sayang part 1 in 2011 there is buruk word spoken by the Tok Dalang. Tok Dalang said Motor buruk pun tak boleh kejar, kau rehatlah dulu (the old motor was not able to chase, you rest first). Tok Dalang said that his motorcycle is already buruk which cannot be chased by her grandchildren. Buruk word in Malay has an equation of form and meaning with the buruk in Banjarese vocabulary. Buruk word in the Malay and Banjarese has the same meaning, that is lama or usang. Hapip (2008, p.21) stated that buruk in Banjarese vocabulary meaning tua (clothes and so on). In Banjarese, the use of buruk word is present in rumah buruk, baju buruk, kain buruk, sepatu buruk, sandal buruk, duitburuk, and others. In Banjarese, the word buruk can also be interpreted as buruk bakas luka (a foul scar), buah buruk (fruit rotten), muntung babau buruk (mouth of the foul-smelling), awaknya babau buruk (his foul-smelling), buruk pahatian (foul his heart), and bakaslukanya babau buruk (former wound stinks).

\subsubsection{Lipas}

In the animation series of Upin and Ipin titled Garang ke Sayang part 2 in 2011 there is lipas word spoken by Cikgu Besar and Jarjit. Cikgu Besar said A lipas, i a lipas, lipas (A cockroach, cockroach, cockroaches) repeatedly. Jarjit said Supaya tak ada lipas (so no cockroaches). Lipas in Malay word has an equation in meaning and form with the word lipas in Banjarese vocabulary. The word lipas in Malay and Banjarese has same meaning, i.e. kecoa. Lipas (cockroaches) based on the Wikipedia Indonesia, the free encyclopedia (https://id.wikipedia.org/wiki/Kecoa) are described below.

Lipas, or cockroaches, Coro is an insect (Class Insecta) of the Blattodea ordo consists of approximately 3,500 species in 6 families. There were cockroaches in almost all parts of the Earth, except in polar regions. Among the most well-known species are the American cockroach, Periplaneta americana, which has a length of $3 \mathrm{~cm}$, the cockroach Blattella germanica, German, with a length of approximately $1 \frac{1}{2} \mathrm{~cm}$, and the cockroach Blattella asahinai, Asian, also with a length of about $1 \frac{1}{2} \mathrm{~cm}$.

In the animation series of Upin and Ipin titled Kembara Kecil-Kecilan part 1 in 2012, there is lipas word spoken by Upin. Upin said Macam mana aka nak bagi, aka kan takut lipas kan...kan? (How about Aka to share, you are fear cockroaches right ... right?). Upin shouted lipas iii. Lipas in Malay has an equation in meaning and form with the word lipas in Banjarese vocabulary. Lipas in Malay and Banjarese means kecoa. 


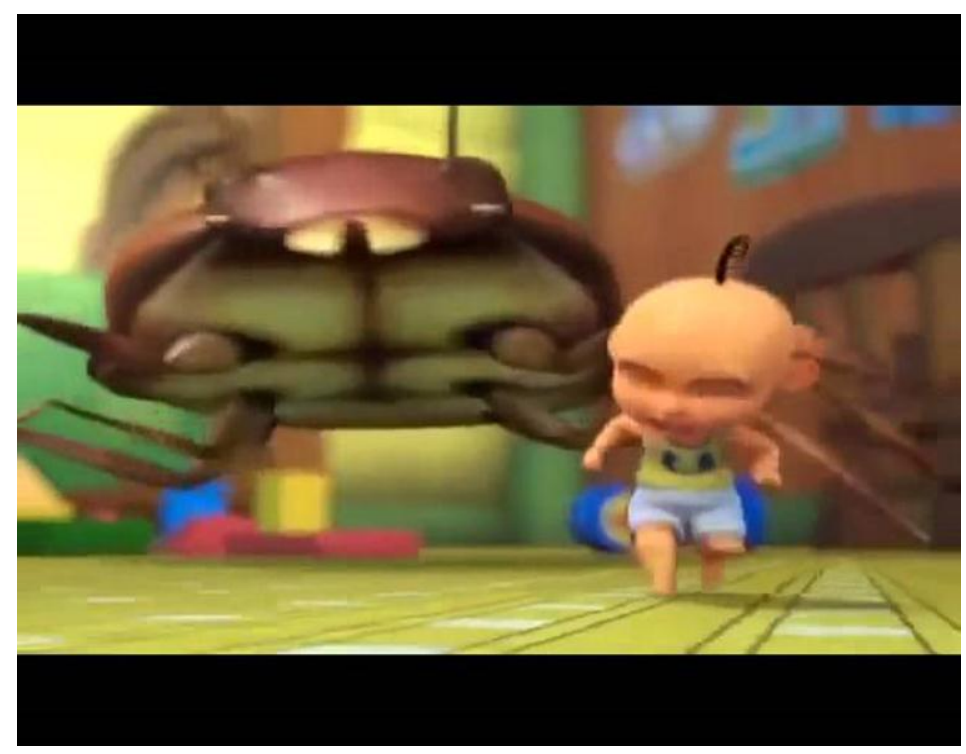

Figure 1. Upin is being Pursued Cockroax

(Source: https://www.wattpad.com/471396352-upin-ipin-musim-6)

\subsubsection{Kur Semangat}

In the animation series of Upin and Ipin titled Kenangan Mengusik Jiwa part 3 in 2012 there is kur semangat spoken by Aziz Sattar. Aziz Sattar said Sayalah, kur semangat. The word kur semangat in Malay has an equation of form and meaning to the word kur semangat in Banjarese. The word kur semangat is a greeting caller or a spirit in the face of life and living. Semangat is the energy or power is inside a human. Aziz Sattar pronounced the word kur semangat after choking on coffee was shocked by Tok Dalang that while breaking and the spelled Betullah Aziz Sattar. In the animation series of Upin and Ipin titled Belajar sambil Main part 1 in 2014 there is kur semangat word spoken by Opah. Opah uttered kur semangat terkejut Opah when surprised at the arrival of Upin and Ipin. The word kur semangat in Malay has an equation of form and meaning to the word kur semangat in Banjarese vocabulary. Kur semangat in Malay and Banjarese is greeting people aghast because surprised by something. In the animation series of Upin and Ipin Opah was surprised cause she old. Kur semangat based on the results of the interview with Prof. Drs. H. Rustam Effendi, M. Pd. Ph.D. on August 15th, 2017 aims to restore the spirit of the weak or missing because something, for example, children or parents are surprised because kepuhunan (got a disaster or Bala because not obey or break the costum). Kepuhunan for break the customs. If going to the forest, people must ask for permission to search for something in the woods. To restore the spirit is family or parents. The habit for, parents who were surprised they said kur semangat for restoring the spirit of their children. Semangat exists in each person's body. Semangat is the form of energy that drives someone to have activity.

\subsubsection{Hang it}

In the animation series of Upin and Ipin titled Beli, Pakai, Suka part 1 in 2013 there is word hang it spoken by Ipin and Opah. Ipin just arrived home suddently smelling hangit (burnt) and then followed by the Opah asked Kak Ros "Ros, apa yang hangit tu?" (Ros, what is burnt?). Hangit in Malay has equation meaning and form with the word hangit in Banjarese vocabulary. Hangit in Malay and Banjarese mean gosong. Hangit is bau seperti bau kerak terbakar atau sangit (Departemen Pendidikan Nasional, 2008, p.480). Smell hangit uttered by Ipin and Opah when smell burnt from the kitchen. After investigation, it turned out that the smell of hangit is derived from pizza cooked by Kak Ros in the oven. 


\subsubsection{Limau}

In the animation series of Upin and Ipin titled Gigi Susu parts 2 in 2013 there is limau word spoken by Mei Mei, Ipin, Upin, Mail, and Ehsan. Mei Mei said Saya pakai kulit limau mandarin (I use mandarin orange skin). Ipin asked Kulit limau lain tak boleh? Kan ada banyak jenis limau? (couldn't use other orange skin? There are many types of orange?). Fizi said Kasturi...kasturi. Upin said Limau manis (sweet orange). Ipin said Purut. Devi asked Nipis bolehkah? The mail said Semua limau tu aku ada, dua singgit (I have all orange, two ringgit). Ehsan said Limau bali rumahku ada banyak, ambil je, kau nak, kau nak (i have bali orange in my house, just take it, if you want) Mei Mei explained Semua limau, haiya, tak tahulah tak tahu, yang saya tahu, mama saya cakap, kalau mau gigi putih, gosok gigi dengan kulit limau, jadi putihlo (all orange, i do not know, just I know, my mother told me, if you want whiter teeth, rub teeth with orange peel, more whiter). Limau in Malay has equation in meaning and form with the word limau in Banjarese. Limau in Malay and Banjarese means jeruk. Limau are plants and fruits including Citrus family and has various types and varieties (Departemen Pendidikan Nasional, 2008, p.828). In the animation series of Upin and Ipin mentioned about the kind of limes. Mei Mei pronounced Kulit limau mandarin. Fizi said Kesturi. Upin uttered Limau manis. Ipin uttered Purut. The girl said Nipis. Ehsan said Limau bali. Limau in Malay means jeruk (Lubis, Sulaiman, Umar, Sinaga, and Shanty, 1993, p.275).

\subsubsection{Merungut}

In the animation series of Upin and Ipin titled Riang Raya part 2 in 2013 there is merungut word spoken by the Opah. Opah said Is jangan merungut depan rezeki, kan kita juga yang nak makan nanti. Patutnya kita bersyukur ada makanan (do not be sullen in front of fortune, we are going to eat later. we have to thankful there is a food). The word merungut in Malay has a semblance of form and meaning with the word merangut in Banjarese vocabulary. The word merungut in the Malay is pronounced merangut in Banjarese. In Indonesian language is pronounced merengut. The word merungut in Malay and merangut in Banjarese vocabulary has the same meaning, namely mengeluh dengan wajah cemberut atau menggerutu. Person merungut or merangut usually shows a face unsightly.

\subsubsection{Umbut}

In the animation series of Upin and Ipin titled Pokok Seribu Guna part 1 in 2014 there is umbut word spoken by Tok Dalang. Tok Dalang said Ini umbut kelapa, sedap dimakan, enak rasanya. Tok Dalang also said umbut ni kalau masak lemak sedap. Umbut in the Malay vocabulary has equation of form and meaning with the word umbut in Banjarese vocabulary. Umbut in Banjarese vocabulary means ujung batang yang masih muda (kelapa, pinang, rotan, dan sebagainya) (Hapip, 2008, p.199). Umbut in animated film Upin and Ipin is eaten raw by the Tok Dalang after cleaned and cut small. In Kamus Besar Bahasa Indonesia (KBBI) there is a description of umbut, that is ujung batang (kelapa, enau, dan sebagainya) yang masih muda dan lunak, dapat dimakan (Departemen Pendidikan Nasional, 2008, p.1525). Specifically for umbut kelapa there is also a definition in KBBI, i.e., pangkal pucuk kelapa yang belum berkembang di puncak pohon (Departemen Pendidikan Nasional, 2008, p.1525). Umbut usually made of coconut milk vegetable. 


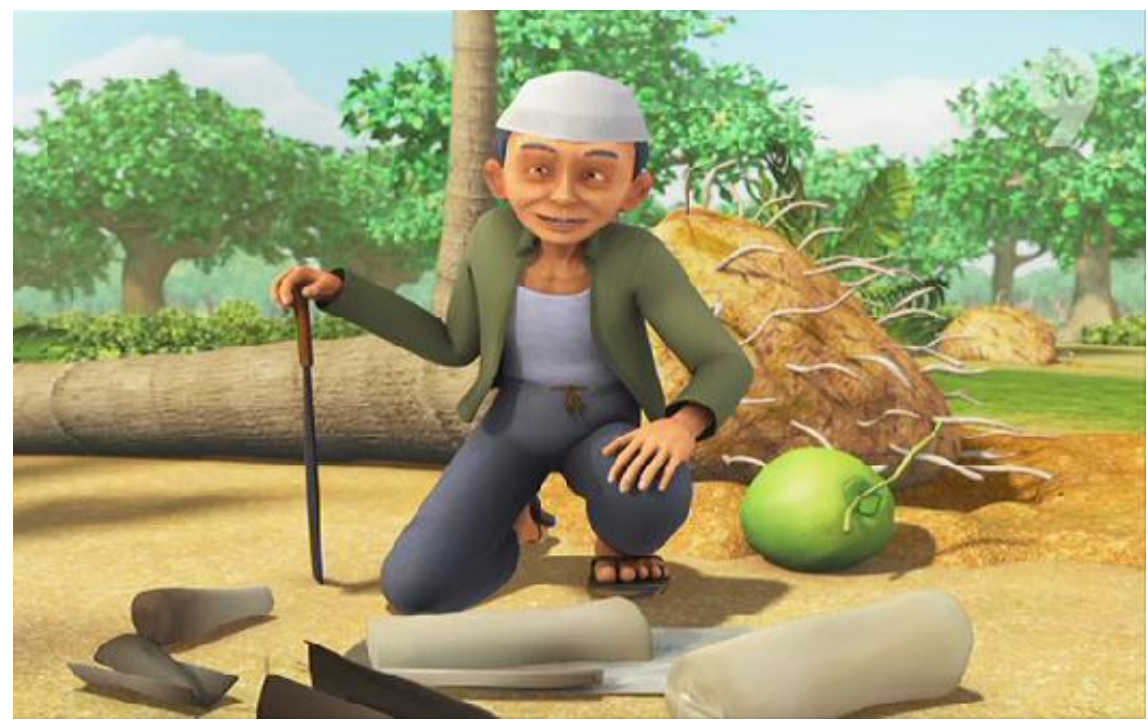

Figure 2. Tok Dalang and Coconut Umbut

(Source: http://ms.upinipin.wikia.com/wiki/Fail:0814_umbut_kelapa.png)

\subsubsection{Tumbung}

In the animation series of Upin and Ipin titled Pokok Seribu Guna part 2 in 2014 there is tumbung word spoken by Tok Dalang. Tok Dalang said Inilah tumbung kelapa, sedap.. Tumbung word in the Malay vocabulary has equation of form and meaning with the word tumbung in Banjarese vocabulary. Tumbung in Malay and Banjarese is buah kecil yang tumbuh dalam buah kelapa yang tua. Tumbung is bakal tumbuhan (pada kelapa) yang berbentuk seperti bola, berwarna putih kekuningan, terletak di dalam bua (Departemen Pendidikan Nasional, 2008, p.1499). Tumbung is in coconuts cutted in half and can be eaten.

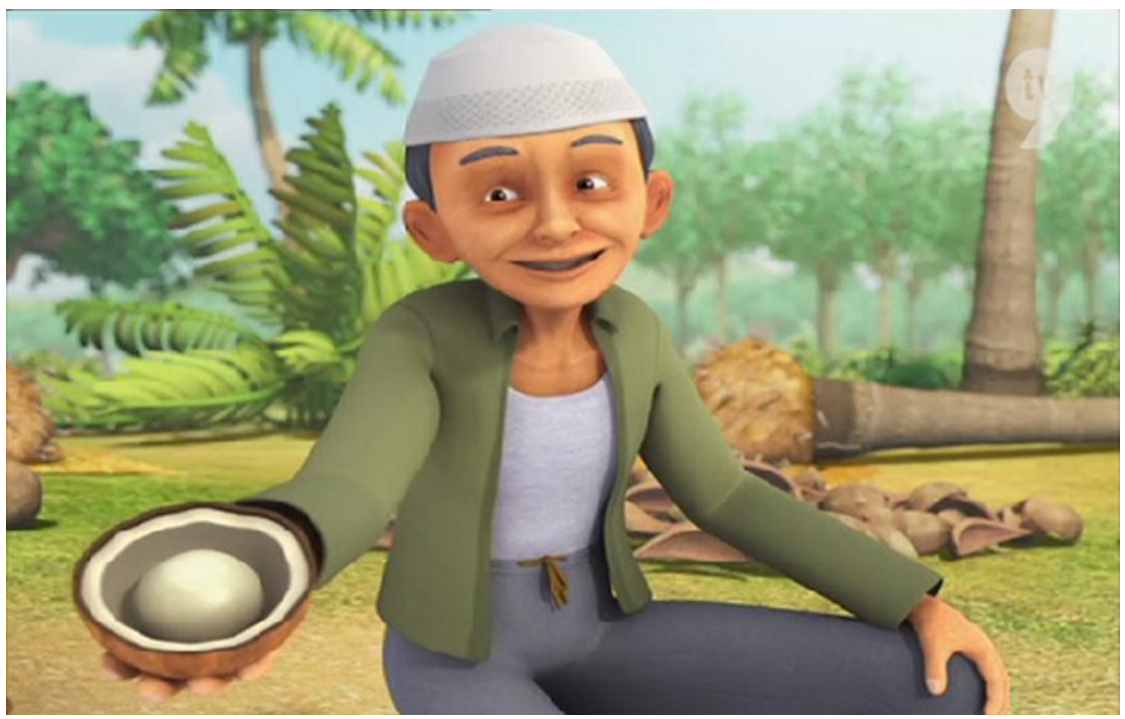

Figure 3. Tok Dalang and Coconut Blow

(Source: http://ms.upinipin.wikia.com/wiki/Fail:0814_tumbung_kelapa.png)

\subsubsection{Sabut}

In the animation series of Upin and Ipin titled Pokok Seribu Guna part 2 in 2014 there is sabut word spoken by Upin. Upin said Tak sangka sabut kelapa pun laku (Not suspected the coconut fibers can be sold to). Sabutin Malay vocabulary has an equation of form and meaning with sabut in Banjarese vocabulary. Sabut is coconut fruit outer skin is already dry and already separated from the 
fruit of coconut shell. SabutIn the animation series of Upin and Ipin is made to sailboats by Tok Dalang to race on the river. Sailboats made Tok Dalang of coir in large quantities and then sold by Mail. Sabut can also be meant as serabut dari kulit luar kering buah kelapa yang sudah dikupasdan terlepas serta terpisah dari tempurung kelapa. In the animation series of Upin and Ipin titled Pokok Seribu Guna part 3 in 2014 there is sabut word spoken by Upin and Ipin. Upin Opah tahu tak?, sabut dengan tempurung kelapa boleh dijual, laku (You know? coconut shell fibers can be sold). Ipin said Bukan tu aja, macam-macam lagi boleh dibuat dengan tempurung dan sabut kelapa (not only that, all kinds of bets made with coconut fibers and shell). Sabut in Malay vocabulary has an equation of form and meaning of the word sabut in Banjarese. Sabut in Malay and Banjarese is kulit luar buah kelapa tua yang sudah terlepas dari kulit keras buah kelapa. Sabut is usually used for washing crockery and cooking utensils in the kitchen. Before use, the coir is first soaked in soapy water for washing. Sabut is kulit yang berserat pada buah kelapa yang bisa dibuat tali atau keset (Departemen Pendidikan Nasional, 2008, p.1198).

\subsubsection{Tempurung}

In the animation series of Upin and Ipin titled Pokok Seribu Guna part 2 in 2014 there is tempurung word spoken by Mail and Upin. The mail said Bukan tu aja, tempurung kelapa pun laku (not only that, coconut shell can be sold to). Upin said Iya di kebun Atok bersepah-sepah tempurung (Yes in the Atok garden scattered (reams) shell). Tempurung in Malay vocabulary has equation of form and meaning to the word tempurung in Banjarese. Tempurung is cangkang keras buah kelapa yang terletak antara daging buah kelapa dengan sabut kelapa kering. Coconut fruit shell could be created to be toy tool clogs, piggy banks (savings), or pot (pot).In the animation series of Upin and Ipin titled Pokok Seribu Guna part 3 in 2014 there is tempurung word spoken by Upin and Ipin. Upin Opah tahu tak?, sabut dengan tempurung kelapa boleh dijual, laku (You know? coconut shell fibers can be sold). Ipin said Bukan tu aja, macam-macam lagi boleh dibuat dengan tempurung dan sabut kelapa (not only that, all kinds of bets made with coconut fibers and shell). Tempurung in Malay vocabulary has equation of form and meaning to the word tempurung in Banjarese. Tempurung in Malay and Banjarese means kulit luar buah kelapa yang keras setelah sabut kelapa. In KBBI, tempurung is kulit buah yang keras (seperti kulit buah kelapa dan sebagainya) atau belahan kulit kelapa yang keras (untuk tempat air dan sebagainya) (Departemen Pendidikan Nasional, 2008, p. 1435). Tempurung kelapa also can be used as a toy bakiak for kids after shell and split into two ropes to lift the legs that are on it.

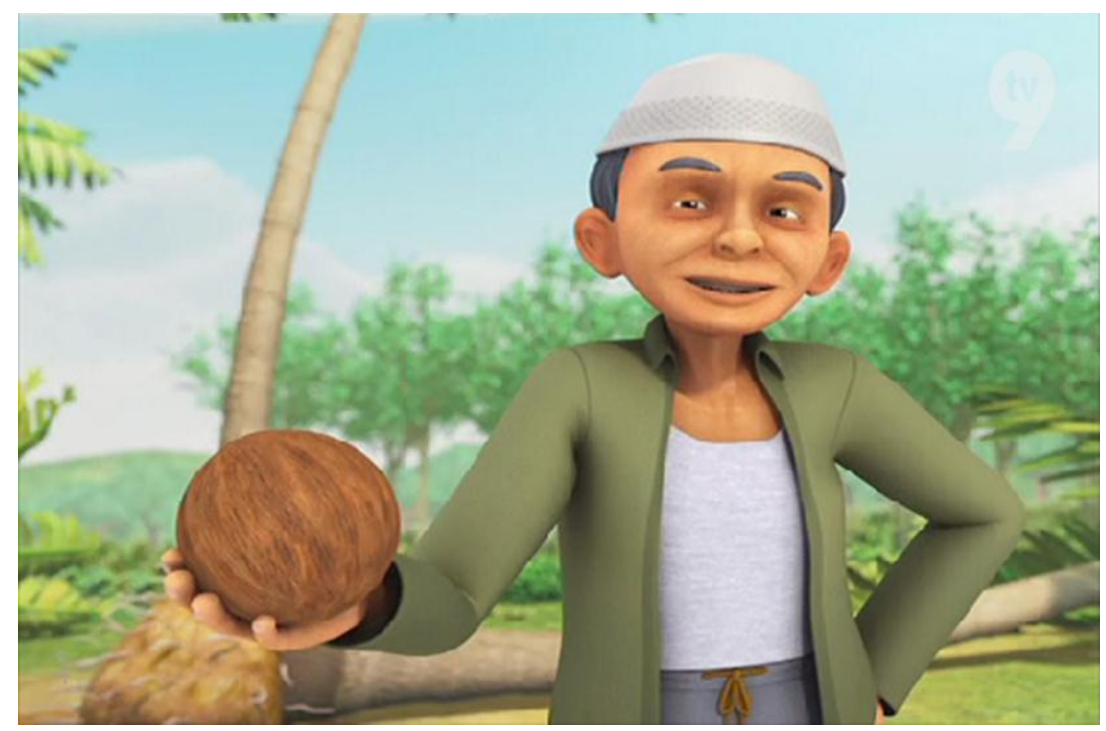

Figure 4. Tok Dalang and Coconut Battle (Source: http://ms.upinipin.wikia.com/wiki/Fail:0814_kelapa_tua.png) 


\subsubsection{Ubat}

In the animation series of Upin and Ipin titled Belajar sambil Main part 1 in 2014, there is ubat word spoken by Opah. Opah uttered $\mathrm{O}$... ubat (O ... medicine) to guess the story of Upin and Ipin about a tablet. Ubat in Malay has an equation in meaning and form with ubat in the Hulu dialect Banjarese vocabulary. Ubat in Malay and Banjarese means obat. Pronunciation of an ubat in the Malay vocabulary is the same as the pronunciation in Hulu dialect Banjarese vocabulary, the letter $\mathrm{O}$ is pronounced [o] be $\mathrm{U}[\mathrm{u}]$ because in his vocal just know letters $\mathrm{A}$ [a], I [i], [u] and U.

\subsubsection{Langsat}

In the animation series of Upin and Ipin titled Hasil Tempatan part 1 in 2014, there is langsat word spoken by Ipin. Ipin said Langsat, Ipin suka langsat (yellow fruits, i like this kind of yellow fruits). Langsat in Malay word has an equation in meaning and form with the word langsat in Banjarese vocabulary. Langsat in Malay and Banjareseis a type of fruit including relatives duku. The famous langsat in South Kalimantan is tanjung langsat. In KBBI explained that langsat was as high as 10-20 $\mathrm{m}$, trunk anyway straight, the flowers are white or yellow, its fruit resembles duku, huddle in bunches, sour-sweet (more acidic rather than duku), thin-skinned, gummy; kokosan; Lansium domesticum; (Departemen Pendidikan Nasional, 2008, p.785).

Based on the description in (http://www.dzargon.com/2016/05/apasih-perbedaan-antara-buahduku-langsat-kokosan.html) about the difference duku fruit, langsat, and kokosan explained that.

Langsat fruit is small and somewhat oval in shape with the size of the fruit resembles the candlenut. This fruit is known to taste sour. Langsat fruit is more oval and solid will fruit, fruit panicles usually contain from 15 up to 30 fruit with seeds the size of a family. Because this amount so that the fruit skin is very rarely found in the form of a rounded whole. Langsat has more gum than duku and fruits tend to be rather transparent. At the time of cooking, laangsat is sweeter than duku and contains more sugar. Because the skin is considered can cause coughing.

\subsubsection{Tilam}

In the animation series of Upin and Ipin titled Dah Bocor part in 2015, there is tilam word spoken by Opah. Opah said Ipin Ipin terkencing atas tilam (Ipin pee on mattress). Tilam in Malay vocabulary has an equation in meaning and form with tilam in the Banjarese vocabulary. Tilam in Malay and Banjarese means Kasur in the Indonesian language. Tilam used as bedding made of kapok inserted into the fabric is stitched rectangle shape somewhat padded so that it rises to fall. Tilam can be drying if exposed to water or exposed to urine. Therefore, tilam can clap with a beater made of rattan which has already been formed to remove dust and former kapok sticking.

\subsubsection{Hancing}

In the animation series of Upin and Ipin titled Dah Bocor part 2 in 2015 there is a hancing word spoken by Fizi and Ipin. Fizi said Hi Ipin mesti tilam Kau bau hancing (Hi Ipin definitely your mattresses smell urinate). Ipin said Tak bau hancing pun (it's no smell at all). Ipin said ... Lagi pun tilam tak bau hancing pun (anyway the mattress does not smell of pee). Hancing in Malay has an equation in meaning and form with the word hancing in Banjarese vocabulary. Hancing in Malay and Banjarese both mean bau pesing akibat buang air kecil. Hancing the ordinary smell if attached to tilam (mattress), pillow, pillowcase, clothing, and case due to urination. Hancing could still smell if tilam (mattress), pillow, pillowcase, clothing, and gloves due to urination when recently dried. Therefore, the tilam (mattress), pillow, pillowcase, clothing, and gloves due to urination should be washed down water in order to smell his hancing (pee smell) lost. 


\subsubsection{Jingkit}

In the animation series of Upin and Ipin titled Dulu dan Sekarang part 1 in 2015 there is jingkit word spoken by Upin. Upin said Jingkit Ipin, nanti lantai kotor kaka marah (walk on tiptoes Ipin, if the floor dirty, Akak will get angry). Jingkit word in the Malay vocabulary has equation of form and meaning with the word jingkit in Banjarese vocabulary. The word jingkit means jinjit or jingkat in the Indonesia language. Jingkit means jingkat (Hapip, 2008, p.69). Jingkit means berjalan dengan menegakkan jari-jari kaki sebagai tumpuan agar telapak kaki yang kotor tidak menyentuh lantai. Berjingkit people who usually walk silently and slowly so as not to caught others.

\subsubsection{Upih}

In the animation series of Upin and Ipin titled Kedai Makan Upin dan Ipin part 1 in 2015, there is a upih word spoken by Ipin. Ipin said Mana boleh tarik upih guna basikal? (Where could pull upih to ride a bike?). Upih in Malay has an equation in meaning and form with the word upih in Banjarese vocabulary. Upih in Malay and Banjarese means tangkai pelepah pinang dan sebagainya yang lebar dan tipis (Departemen Pendidikan Nasional, 2008, p.1534). Upih means selodang (Hapip, 2008, p.201). In the animation series of Upin and Ipin are shown racing draws upih games conducted by Ipin and Upin, Fizi and Ehsan, and Mail and Mei-Mei. In the match, the race attracts upih, Mail and MeiMei win. This is because Mail using the bike to pull upih and Mei-Mei. Ipin falls towards the end of the race because of a leg stumbling stone.

\subsubsection{Siang}

In the animation series of Upin and Ipin the titled Siapa Atan? Part 3 in 2015 there is siang word spoken by Atan. Atan said Tok tok tok, Ini Atan bawa boleh mancing dapat ikan keli dua ekor besarbesar, Atok siang ya? (Tok tok tok, Atan brings two large keli fish, Atok cleans the scale?). The word siang in Malay vocabulary has equation of form and meaning with word siang in Banjarese vocabulary. The word siang in Malay and Banjarese has the same meaning, namely yaitu buang atau bersihkan sisik, duri, mulut, ekor, dan sirip, isi kepala, dan perut ikan.

\subsubsection{Keli}

In the animation series of Upin and Ipin the titled Siapa Atan? part 3 in 2015 there is keli word spoken by Atan. Atan said Tok tok tok, Ini Atan bawa boleh mancing dapat ikan keli dua ekor besarbesar, Atok siang ya? (Tok tok tok, Atan brings two large keli fish, Atok cleans the scales?). The word keli in Malay vocabulary has an equation of form and meaning to the word keli in the Banjarese vocabulary. Keli in Malay and Banjar has the same meaning, namely the types of fish such as catfish.

Keli fish are freshwater fish that are found in many ASEAN countries, especially Malaysia. In some places, especially in Selangor, keli fish is referred to as "ikan semilang". For the people of Perak, semilang fish only live in the sea. Keli fish can be found in most rice paddy fields, for example in Pahang, Paya Pahang Tua, Mambang, Ganchong, and Paloh Hinai. It is also available at Tasik Chini, Paya Bungor, or Bera. Keli also inhabits such a small river mouth as Sungai Lepar in Paloh Hinai to Jerantut and Kuala Lipis, in addition to Sungai Bera and Sungai Serting (https://ms.wikipedia.org/wiki/Ikan_Keli).

\subsubsection{Ular Sawe or Ular Sawa}

In the animation series of Upin and Ipin titled Patuk Kau part 2 in 2016, there is ular sawe or ular Sawa word spoken by the Tok Dalang. Tok Dalang Itu ular sawe (sawa), ular sawe (sawa) dia tak patuk orang, tapi belit orang sampai kiok, jangan buat main. The word ular sawe or ular sawa in the Malay vocabulary has an equation of form and meaning to the word ular sawa in the Banjarese vocabulary. Ular sawe or ular sawa, known as the snake python. Ular sawe or ular sawa did a 
collision on its prey, twisted and crushes its prey's body, and then swallow it. Ular sawe or ular sawa is ular sanca (Hapip, 2008, p.167).

\subsubsection{Kelulut}

In the animation series of Upin and Ipin titled Bila Cuti Sekolah part 1 in 2016 there is kelulut word spoken by Tok Dalang. Tok Dalang said kelulut in relation to bees kelulut. Tok Dalang said Ini lebah kelulut, tak sengat orang (bees kelulut, This does not sting people). Kelulut in Malay has equation in meaning and form with the word kelulut in Banjarese vocabulary. Kelulut in Malay and Banjarese is the name of a type of bee that produce honey. Kelulut bees kept people to take honey. Kelulut bees do not sting like other bees. Kelulut is smaller and huddle near the house or the nest.

Kelulut bees or kelulut only (also called meliponini) is not has sting which produces honey just like honey bees. .... Kelulut storing honey in small jars covered with propolis. .... It feels a little acerbic than honey bees. .... (https://ms.wikipedia.org/wiki/Lebah_kelulut).

Based on the above quote can be known that kelulut bees does not has sting. Kelulut is the bees also produce honey just like honey bees. Kelulut storing honey in small jars covered with propolis. Kelulut honey taste slightly sour. In the animation series of Upin and Ipin titled Bila Cuti Sekolah part 2 in 2016 there is kelulut word spoken by Tok Dalang. Tok Dalang said Eh Fizi jangan, nanti tersedot kelulut and corong lain-lain bentuk ni, maknanya lebah kelulut yang berlainan jenis, paham. Kelulut in Malay has equation in meaning and form with the word kelulut in Banjarese vocabulary. Kelulut in Malay and Banjarese mean jenis lebah.

\subsubsection{Masam}

In the animation series of Upin and Ipin in the animated film of Upin and Ipin titled Bila Cuti Sekolah part 2 in 2016 there is Masam word spoken by Mei Mei. Mei Mei said Ih kecut, masam, we, tak suka-tak suka, tak mau makan (Ih sour, we did not like it, didn't want to eat). The word Masam in Malay vocabulary has an equation of form and meaning with the word Masam in Banjarese vocabulary. The word Masam in Malay and Banjarese has the same meaning, that is rasa asam. Mei Mei in part 2 said the word Masam when trying to eat cereme. Mei Mei accidentally eats cermai yet ripe. In the animation series of Upin and Ipin in the animated film of Upin and Ipin titled Bila Cuti Sekolah part 3 in 2016 there is Masam word spoken by Mei Mei and Upin. Mei Mei in part 3 said Tak suka-tak suka, masam (does not like it, acid). Upin said Masam. The word Masam in Malay vocabulary has an equation of form and meaning with the word Masam in Banjarese vocabulary. In Malay and Banjarese, masam means rasa asam.

\subsubsection{Janggut}

In the animation series of Upin and Ipin titled Di Sebalik Tabir part 2 in 2017 there is janggut word spoken by Ipin. Ipin said janggut panjang. Janggut in Malay has an equation in form and meaning with janggut in the Banjarese vocabulary. Janggut in Malay and Banjarese means jenggot in the Indonesian language. Janggut is hair that grows on the chin. Janggut may also be grey hair-like hair when the dude is old. In KBBI explained that janggut is fur that grows on the chin; beard (Departemen Pendidikan Nasional, 2008, p.564). Blust (Purwo \& Collins, 1985, p.128) defines janggut as the hair that grows on the chin (human).

\subsubsection{Menoreh}

In the animation series of Upin and Ipin titled Mainan Baru part 2 in 2017, there is a menoreh word spoken by Kak Ros. Kak Ros said Pergi menoreh kat ladang Ah Tong (Go incise near fields Ah Tong). Kak Ros said it after asked by Upin, Mana Opah?. Menoreh in Malay has a semblance of form and meaning with the word manurih in Banjarese vocabulary. Menoreh in Malay word pronounced menurih or manurih in Banjarese. The word menoreh in Malay and manurih in Banjarese vocabulary 
means harvesting getah (gum) by the scrape of rubber tree branches to remove the resin. Nicks or scratches in the rubber tree limb made obliquely so that gum can trickle down to the shelter had been provided. The word menoreh in Malay and manurih in Banjarese vocabulary also spoken memantat (mamantat) gatah in Banjarese vocabulary in Sampit. Mamantat gatah has same meaning with menoreh or manurih. Mamantat gatah means scraping rubber tree trunks with a slanted position to take out or shed to shelter that had been prepared.

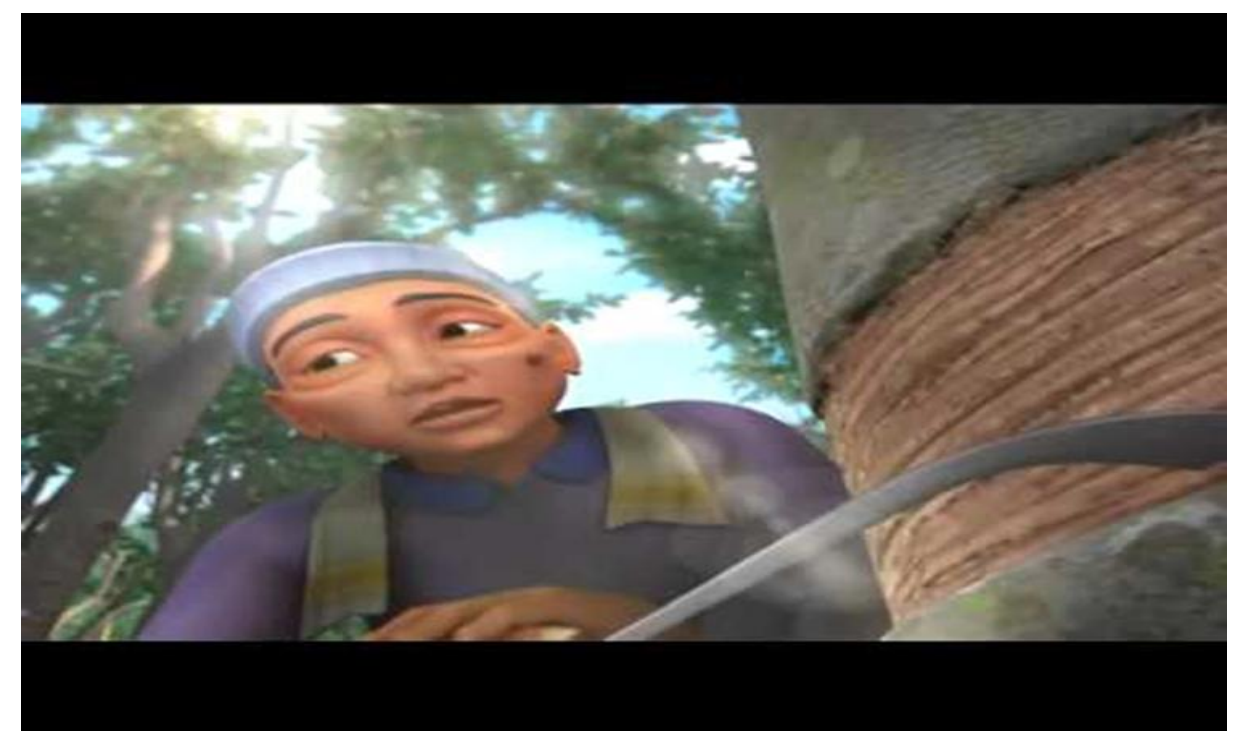

Figure 5. Opah scratching a rubber tree to remove its sap (Source: https://www.youtube.com/watch?v=k-Fcq9s3nuY)

\subsubsection{Biji Getah}

In the animation series of pin and Ipin titled Mainan Baru part 2 in 2017 there is biji getah word spoken by Ipin. Ipin said Biji getah, Upin kita main lagi biji getah, siapa pecah dulu, dia kalah (rubber seeds, Upin we play seed gum battle, who broke first, he lost). The word biji getah in Malay has a semblance of form and meaning with the word bigigatah in Banjarese vocabulary. Biji getah in the Banjarese vocabulary called bigi gatah is biji pohon getah yang sudah kering. Dried Biji getah is already commonly used by the boys for play break down the biji getah. There is played by pressing both the kernels of biji getah with both palms of the hand. There are also played with put biji getah both in joining with others and then struck with the palm. If it is broken then the owner of the biji getah is lost. Biji getah should not be placed under the broken and lost, there are times when biji getah placed on the well could rupture. Therefore, biji getah in Sampit, Central Kalimantan province also named bigi gapok. Biji getah when the researcher was little in elementary school in Sampit, many found in the river. So, not under or near the tree. Recently when the researcher moved to Banjarbaru follow his parents, the researcher found seeds of biji getah under the tree. In Banjarbaru, South Kalimantan in 1992, researcher heard bigi pedak to mention bigi gapok or biji getah. The researcher hears directly from his teammates playing biji getah.

\subsubsection{Getah}

In the animation series of Upin and Ipin titled Mainan Baru part 2 in 2017 there is getah word spoken by Upin. Upin said Kita orang kumpul getah, uncle (we gathered rubber, uncle). Getah in Malay has a semblance of form and meaning with gatah in Banjarese vocabulary. Getah in Malay or gatah in Banjarese vocabulary means the rubber already accumulated and hardened in the cup. Gum shaped like bowls and then weighed and judged its money on the rubber gatherers. In the animation series of Upin and Ipin titled Mainan Baru part 3 in 2017 there is getah word spoken by Kak Ros. Kak Ros said Baupun dah macam getah, pergi mandi cepat (smells like gum, go take a bath quickly). 
Getah in Malay has a semblance of form and meaning with the word gatah in Banjarese vocabulary. Getah in Malay and thegatah in Banjarese vocabulary has the same meaning, that is getah dari pohon karet or karet. Getah in an animation series ofUpin and Ipin refers to the rubber of the rubber tree. The word getah in Banjarese vocabulary can also mean the rubber to catapult game or a rubber band. Besides, getah in Banjarese also means the rubber from fruit or wood or tree. In Banjarese, there are sentences bajunya kana gatah (his clothes got gum).

\subsubsection{Urutkan}

In the animation series of Upin and Ipin titled Mainan Baru part 3 in 2017 there is urutkan word spoken by Ipin. Ipin said Opah biar Ipin urutkan, ha sedap tak? (Granma, let ipin massage let, is it good?). Then Ipin said Upin kau urutkan sana (Upin you massage there). Urutkan word in Malay vocabulary has equation of form and meaning with urutkan in Banjarese vocabulary. Urutkan in Malay and Banjarese has same meaning, i.e. pijatkan. Upin and Ipin massage the Opah's fatigue foot. In this usage, the word urut which means pijat can be as baurut (ask for a massage), maurutakan (massage), and paurutan (a masseur).

\subsubsection{Luruh}

In the animation series of Upin and Ipin titled Kembara 6 Musim part 1 in 2017, there is luruh word spoken by Kak Ros and Ehsan. Kak Ros said Musim bunga, musim panas,musim luruh, dan musim salji (spring, summer, fall, and winter). Ehsan said Ini musim luruh (autumn). Luruh in Malay has an equation of form and meaning with luruh in Banjarese vocabulary. Luruh in Malay and Banjarese meaning gugur or jatuh in Indonesia language. In the film the Upin and Ipin luruh related to the autumn (fall). Luruh (autumn) is the season where the leaves and flowers tumbling. Luruh in the Banjarese vocabulary could also be used to declare the luruh hair or luruh feather.

\subsubsection{Gugur}

In the animation series of Upin and Ipin titled Kembara 6 Musim part 1 in 2017, there is a gugur word spoken by Ehsan. Ehsan said Penuh ke tanah,daun-daun dan bunga-bunga gugur (full to the ground, the leaves and the flowers fell). Gugur in Malay vocabulary has an equation of form and meaning with word gugur in Banjarese vocabulary. Gugur in Malay and Banjarese meansjatuh. In Banjarese, gugur was also associated with someone who has been knocked off the bike or run. Gugur in Banjarese can also be pronounced if there was something drop in the height of objects such as cups, plates, or bottles falls from the top of the table. So not only on fruit, leaves, twigs or branches gugur word used.

\subsubsection{Mangga Jeruk}

In the animation series of Upin and Ipin titled Terlajak Laris part 2 in 2017, there is mangga jeruk word spoken by Dato Sri Aliff Shukri. Dato Sri Aliff Shukri Abang nak buat mangga jeruk (Abang want to make the mango orange). That answer he gave after being asked by Upin why did buy many mango? Upin asked Aka beli mangga banyak-banyak ni untuk apa? Dato Sri Aliff Shukri replied Abang nak buat mangga jeruk (Abang want to make the mango orange). The word mangga jeruk in Malay has a semblance of form and meaning with mangga jaruk in Banjarese vocabulary. In Banjarese, the word mangga jeruk in Malay spoken mangga jaruk. Mangga jeruk in Malay and mangga jaruk in Banjarese vocabulary is the mango peeled and sliced according to taste and then marinated or sweetened water which stored in the jar.

\subsubsection{Mempelam Jeruk}

In the animation series of Upin and Ipin titled Terlajak Laris part 2 in 2017, there is mempelam jeruk word spoken by Dato Sri Aliff Shukri. Character named Dato Sri Aliff Shukri said Tengok kauorang menjual ni,teringat abang waktu kecil-kecil dulu, jualmangga jeruk, mempelam jeruk (see 
you people sell ni, remembered me, while child was selling mango orange, mempelam orange). Ipin then asked Dato Sri Aliff Shukri E ...mangga dan mempelam tu tak samakah? (E ... manggo and mempelam are not same?). Dato Sri Aliff Shukri then said sama.Mempelam jeruk word in Malay has a semblance of form and meaning with hampalam jaruk in Banjarese vocabulary. Mempelam jeruk in Malay or hampalam jaruk in Banjarese vocabulary is the mempelam fruit which peeled and sliced according to taste and then marinated or sweetened. Mempelam jeruk in the Malay vocabulary spoken hampalam jaruk or palam jaruk in Banjarese vocabulary. Mempelam is kind of young mango fruit.

\subsubsection{Masin}

In the animation series of Upin and Ipin titled Terlajak Laris part 2 in 2017, there is masin word spoken by Dato Sri Aliff Shukri. Dato Sri Aliff Shukri said Lagiabang jualkacang masin, telor masin, banyak lagilah buat perniagaan kecil-kecilan (im also selling salted peanuts, salted egg, many more). A character named Dato Sri Aliff Shukri said that in a little time he had sold kacang masin and telor masin. Masin in the Malay vocabulary has an equation of form and meaning with masin in Banjarese vocabulary. Kacang masin in Malay and Banjarese has the same meaning, namely kacang asin. The word Telor masin in Malay and Banjarese has the same meaning, namely telur asin. So, masin in Malay and Banjarese has the same meaning, that is asin. Masin in Malay and Banjarese associated with saltiness caused by sprinkling salt on the food or a mixture. For nut and egg tastes salty so it's salted by salt. The existence of salt causes the nut and egg are called to be soy sauce and salty eggs.

\subsubsection{Buruk Siku}

In the animation series of Upin and Ipin titled Masih Ada Sayangpart 3 in 2017 there is buruk siku word spoken by Ipin. Ipin uttered Buruk siku after Ehsan asked back items that he has given to Upin. Ehsan asked to Upin Kau ada ambiltrak mainan warna orangekan? (Did you took an orange truck toy?). Upin answered Ada, kau bagi (yes, you give). Ehsan then said Minta balik (give me back). Ipin said Dah bagi, mana boleh minta balik, buruk siku tahu? (its given, could not get back, buruk siku?). Ehsan said Tahu. Tapi trak orange tu penting sangat. Aku kena dapatkan balik. Kalau tidak, Fizi merajuk. (i know. But the orange truck orange is important. I have to get back. Otherwise, Fizi will sulk). The phrase buruk siku in Malay has a semblance of form and meaning with the phrase buruk sikuan in Banjarese vocabulary. Buruk siku in Banjarese vocabulary spoken buruk sikuan. Buruk siku in Malay and buruk sikuan in Banjarese vocabulary has the same meaning, namely an expression of satire for people who pull back stuff awarding.

\subsubsection{Merajuk}

In the animation series of Upin and Ipin titled Masih Ada Sayang part 3 in 2017 there is merajuk word spoken by Ehsan, Upin and Ipin. Ehsan said Tahu. Tapi trak orange tu penting sangat. Aku kena dapatkan balik. Kalau tidak, Fizi merajuk (i know. But the orangetruck is important. I have to get back. Otherwise, Fizi will sulk). Then Upin and Ipin said simultaneously Fizi merajuk. Merajuk in Malay has a semblance of form and meaning with the word meraju or maraju in Banjarese vocabulary. Merajuk in Malay has the same meaning as meraju or maraju in Banjarese, i.e. ngambek or mengambek..

\subsubsection{Ikan Buntal}

In the animation series of Upin and Ipin titled Teroka Lautan part 1 in 2017, there is buntal fish spoken by the angelfish by Upin. In the animation series of Upin and Ipin, buntal fish is portrayed by Ehsan. Buntal fish in Wikipedia, the free encyclopedia is described as below.

Buntal fish (family: Tetraodontidae) is a family of the estuaries fish and the sea fish comes from ordo Tetraodontiformes. In morphology, the similar fish that are included in this family are similar to 
the porcupine fish which have a large wide spine (unlike spine thinner Tetraodontidae, hidden, and can be seen when the fish is swollen). (https://id.wikipedia.org/wiki/Ikan_buntal).

Ikan buntal is a fish that can swell its body and bite its prey so strong. Ikan buntal can make a hole with bite marks on the soles of the feet of humans when bitten. The wound round holes fit the big mouth. In fact, the ikan buntal also eats meat on the sole of human feet when bitten. Ikan buntal in Malay has a semblance of form and meaning with iwak buntal in Banjarese vocabulary. Ikan buntal in Malay or iwak buntal in Banjarese vocabulary has the same meaning, namely ikan yang bisa membesarkan atau menggembungkan diri atau badannya. Even when the ikan buntal is captured and removed from the water and then rubbed his body parts would be bulging or distended too.

\subsubsection{Tempah}

In the animation series of Upin and Ipin titled Masak-Masak in 2018 there is Masak-Masak word spoken by Upin. Upin said Ini bukan untuk Uncle Muthu, ini ada orang lain tempah (this is not for Uncle Muthu, this is other person order). Tempah in Malay has semblance of form and meaning with the word tampah in Banjarese vocabulary. Tempah word in Malay and tampah in Banjarese vocabulary has the same meaning, that is the pesan. Hapip (2008, p.180) stated tampah means pesan. In Banjar there is the use of the word tampahan (order), batampah (command or order), manampahi (originally booked), and ditampahi (ordered).

Table 1. Similarities of Malay Vocabulary in Upin and Ipin Animated Films with Banjarese Vocabulary in South Kalimantan

\begin{tabular}{llllll}
\hline Malay vocabulary in & Banjarese vocabulary in & South & Meanings in & Reconstruction & of \\
the animated films & Kalimantan & & & Indonesian & Etimon PAN (Proto- \\
Upin and Ipin & & & & & Austronesian) (Kawi, \\
& & & & Durasid, \& Effendi, \\
& & & & 1993 )
\end{tabular}

\begin{tabular}{|c|c|c|c|}
\hline Simbah & Simbah & $\begin{array}{l}\text { Flush or } \\
\text { splash } \\
\text { (Malay), keep } \\
\text { (Banjarese) }\end{array}$ & - \\
\hline Basuh & Basuh & Washing & ba'uh \\
\hline Sorang & Sorang & Own or itself & - \\
\hline Hentam (hantam) & Hantam & Hit & - \\
\hline Semalam & Semalam (samalam) & $\begin{array}{l}\text { Yesterday or } \\
\text { last night }\end{array}$ & - \\
\hline Ma ... abah & Ma ... abah & $\begin{array}{l}\text { Mom } \quad \cdots \\
\text { father }\end{array}$ & - \\
\hline Keranggeataukerangga & Keranggaataukaranggaatausamutkarangga & $\begin{array}{l}\text { Large red } \\
\text { ants }\end{array}$ & - \\
\hline Putik & Putik & Pick, picking & putik \\
\hline Penat & Panat & Tired & panad \\
\hline Sorang & Sorang & Own or itself & - \\
\hline Dodol & Dodol & $\begin{array}{l}\text { Taffy made } \\
\text { of sticky rice, } \\
\text { coconut milk, } \\
\text { and palm }\end{array}$ & $\begin{array}{l}\text { Kata } \\
\text { pinjamandaribahasaJawa }\end{array}$ \\
\hline
\end{tabular}




\begin{tabular}{|c|c|c|c|}
\hline & & $\begin{array}{l}\text { sugar (often } \\
\text { with durian) }\end{array}$ & \\
\hline Parut & Parut & Shaved & parutataupa!ut \\
\hline Laju & Laju & Fast & - \\
\hline Isuk & Isuk & Tomorrow & hisukatau 'it'uk \\
\hline Kawah & Kawah & $\begin{array}{l}\text { Crock, } \\
\text { cauldron or } \\
\text { large frying } \\
\text { pan }\end{array}$ & kawaqataukavah \\
\hline Kacau & Kacau & Stir or mix & kacau \\
\hline Sunat & Sunat & Circumcision & - \\
\hline Buluh & Buluh & Bamboo & buluh \\
\hline Burungbubut & Burungbubut & Bubut bird & bulung \\
\hline Buruk & Buruk & $\begin{array}{l}\text { Ugly, old, } \\
\text { shabby, or } \\
\text { worn out }\end{array}$ & $\begin{array}{l}\text { bu } \sqrt{ } \text { uk (Blust (1985: 50) } \\
\text { states that PAN } \\
\text { forburukisbuRuk). }\end{array}$ \\
\hline Lipas & Lipas & Cockroaches & 'ipat' \\
\hline Kur semangat & Kur semangatataukursumangat & $\begin{array}{l}\text { The speech of } \\
\text { the giver or } \\
\text { preacher, aziz } \\
\text { Sattar's } \\
\text { speech when } \\
\text { surprised by } \\
\text { Tok Dalang }\end{array}$ & $\mathrm{ku}(!)$ t'umayat \\
\hline Hangit & Hangit & $\begin{array}{l}\text { Burnt, smells } \\
\text { like burning }\end{array}$ & t'anit \\
\hline Limau & Limau & $\begin{array}{l}\text { Orange or } \\
\text { citrus }\end{array}$ & limav \\
\hline Merungut & Merangut & Whining & - \\
\hline Umbut & Umbut, humbut & $\begin{array}{l}\text { The tip of the } \\
\text { trunk } \\
\text { (coconut, } \\
\text { enau, etc.) } \\
\text { that is young } \\
\text { and soft, can } \\
\text { be eaten or } \\
\text { the base of } \\
\text { the } \\
\text { undeveloped } \\
\text { coconut } \\
\text { shoots at the } \\
\text { top of the tree }\end{array}$ & 'u(m)bu[dg'] \\
\hline Tumbung & Tumbung & $\begin{array}{l}\text { Will plants } \\
\text { (on coconut) } \\
\text { shaped like a } \\
\text { ball, }\end{array}$ & - \\
\hline
\end{tabular}




\begin{tabular}{|c|c|c|c|}
\hline & & $\begin{array}{l}\text { yellowish- } \\
\text { white, located } \\
\text { in the fruit }\end{array}$ & \\
\hline Sabut & Sabut & $\begin{array}{l}\text { Coconut peel } \\
\text { fibers to wash } \\
\text { glassware } \\
\text { including } \\
\text { pots, pans, } \\
\text { spoons, forks, } \\
\text { and others. }\end{array}$ & t'abut \\
\hline Tempurung & Tempurung & $\begin{array}{l}\text { Hardshell of } \\
\text { the coconut } \\
\text { fruit }\end{array}$ & - \\
\hline Ubat & Ubat & Drug & $\mathrm{u}(\mathrm{bb}) \mathrm{at}$ \\
\hline Langsat & Langsat & Langsat fruit & la(n)t;at \\
\hline Tilam & Tilam & Mattress & tilam \\
\hline Hancing & Hancing & $\begin{array}{l}\text { Stench of } \\
\text { urine }\end{array}$ & ka(k)k'in \\
\hline Jingkit & Jingkit & $\begin{array}{l}\text { Stand or walk } \\
\text { on tiptoes }\end{array}$ & - \\
\hline Upih & Upih & $\begin{array}{l}\text { Stalks of } \\
\text { betel nut and } \\
\text { so on are } \\
\text { wide and thin }\end{array}$ & 'upih \\
\hline Siang & Siang & $\begin{array}{l}\text { Remove } \\
\text { scales, spines, } \\
\text { mouth, tail, } \\
\text { fins, and fish } \\
\text { head and } \\
\text { stomach } \\
\text { contents }\end{array}$ & - \\
\hline Keli & Keli & Keli fish & - \\
\hline Ularsaweatauularsawa & Ularsawa & python & 'ula $\sqrt{ }$ t'ava \\
\hline Kelulut & Kelulut & $\begin{array}{l}\text { Kelulut, } \\
\text { kelulut bee or } \\
\text { kelulut honey }\end{array}$ & - \\
\hline Masam & Masam & Acid & - \\
\hline Janggut & Janggut & $\begin{array}{l}\text { Beard(hair } \\
\text { growing on } \\
\text { chin } \\
\text { (human)) }\end{array}$ & zaNgutord'angut \\
\hline Menoreh & Manurih & $\begin{array}{l}\text { Slicing not } \\
\text { too deeply } \\
\text { (on the bark } \\
\text { and so on, } \\
\text { scraping, }\end{array}$ & - \\
\hline
\end{tabular}




\begin{tabular}{|c|c|c|c|}
\hline & & $\begin{array}{l}\text { slicing } \\
\text { (hacking) to } \\
\text { open, tapping }\end{array}$ & \\
\hline Bijigetah & Bigigatah, bigigapok, bigipedak, bigi para & $\begin{array}{l}\text { Sap seeds, } \\
\text { rubber tree } \\
\text { fruit }\end{array}$ & bid'[i] ga(t)ah \\
\hline Getah & Gatah & Rubber & $\mathrm{ga}(\mathrm{t}) \mathrm{ah}$ \\
\hline Urutkan & Urutkan & Massage & 'u!ut \\
\hline Luruh & Luruh & fall & - \\
\hline Gugur & Gugur & fall & - \\
\hline Mangga jeruk & Mangga jaruk & $\begin{array}{l}\text { Marinated or } \\
\text { sweetened } \\
\text { mangoes }\end{array}$ & mayga' d'a!uk \\
\hline Mempelamjeruk & Hampalamataupalamjaruk & $\begin{array}{l}\text { Salted or } \\
\text { sweetened } \\
\text { ripe fruit }\end{array}$ & palamd'a!uk \\
\hline Masin & Masin & Salty & 'at'in \\
\hline Buruk siku & Buruksikuan & $\begin{array}{l}\text { An } \\
\text { expression } \\
\text { for the person } \\
\text { who asks for } \\
\text { the return of } \\
\text { an item or } \\
\text { something } \\
\text { that has been } \\
\text { given }\end{array}$ & bu $\sqrt{ }$ uk \\
\hline Merajuk & Merajuataumaraju & Sulking & - \\
\hline Ikan buntal & Iwak buntal & Puffer fish & - \\
\hline Tempah & Tampah & Order & - \\
\hline
\end{tabular}

\section{Discussion}

Malay vocabulary contained in the animation series Upin and Ipin, there has the same form and meaning as the Banjarese vocabulary in South Kalimantan. The vocabulary of Malay and Banjarese that has an equation of meaning and form because both of them are Austronesian language family. For the basuh word, there is a difference in the determination of PAN by Kawi, Durasid, \& Effendi (1993) with Adelaar (2004). Kawi, Durasid, \& Effendi (1993, p.98) stated that the PAN for basuh is ba'uh, whereas Adelaar $(2004$, p.22) stated that the PM for the basuh is *basuh.

The sorang word is indeed a Banjarese vocabulary. It is found in Kamus Banjar Indonesia by Hapip (2008, p.173), sorang means saya or sendiri. Sorang also spelled sawrang in the Banjarese hulu dialect (Hapip, 2008, p.167; Kawi, 2002, p.33). For ma ... abah (mother ... father) word, Kawi (2002, p.225-226) explains that the word $m a$ (mother) in Banjarese has variation such as Uma, mama, and indung, while said abah (father) to have variant pronunciations, namely abah, abap, ayah, bapa, and apang. For ma, Kawi, Durasid, \& Effendi (1993, p.67) used the word $i b u$. For the said abah, Kawi, Durasid, \& Effendi (1993, p.43) use the word ayah or bapa. This is because Proto Malayo (PM) to abah is PM *ayah (Adelaar, 2004, p.22). 
The word kerangge or kerangga in Malay and Banjarese vocabulary is an Austronesian language family. The word kerangge or kerangga also in old Javanese, namely kararayga. Kararayga is a large red tree ant (Zoetmulder \& Robson, 2006, p.462). For the dodol word, Nothofer (2009, p.23-24) stated that the word dodol in the Malay vocabulary is an Austronesian loan word from the source exactly the Java language. In the Java language, the dodol means kue atau sejenis penganan. In old Javanese, dodol comes from the word dwadwal. Dwadwal or dodol is dodol or name of the food made from glutinous rice flour and sugar (Zoetmulder \& Robson, 2006, p.242)

The word laju is indeed contained in the Banjarese vocabulary, this is found in Kamus Banjar Indonesia by Hapip (2008). Hapip (2008, p.99) stated that laju means cepat or segera. In Banjar, there is indeed the same meaning word with the laju, namely capat (fast), lakas (quick), and (h)ancap. Therefore, Kawi, Durasid, \& Effendi (1993, p.69) just entered capat in the research of Refleksi Etimon Proto Austronesia dalam bahasa Banjar. The word capat has reflection etimon PAN, i.e. k'apat. Kawi (2002, p.314) added sikap to state cepat in Banjar.

The word kawah which means kuali besar or wajan besar in the Malay and Banjarese vocabulary. The word kawah in Banjarese vocabulary has the PAN *kawaq (Kawi, Durasid, \& Effendi (1993, p.26). The word kawah is a Malay vocabulary result based on the research of Blust (2005, p.238). Kawah to describe Kuali Besar or wajan Besar in Malay and Banjarese is estimated to be chosen because it resembles the shape of a rounded crater, wide and spacious. Therefore, in the old Javanese language, kawah means kawah (Zoetmulder \& Robson, 2006, p.474). In the Java language, the word kawah means jalan api di dalam gunung (Mangunsuwito, 2009, p.380).

The word penat in the Malay vocabulary spoken panat in Banjarese. In Banjarese, also known as uyuh and lapah beside panat. The word uyuh means to capai (capek), lelah or letih. The word lapah means capai (capek), lelah, or letih.

The word sunat is a vocabulary of Malay and Banjarese vocabulary. In Malay and Banjarese, the word sunat means potong kulit luar penutup bagian depan kepala penis (male genital). In Kamus Besar Bahasa Indonesia, sunat is berpotong kulup atau khitan (Departemen Pendidikan Nasional, 2008, p.1355). In the Java language is found the word sunat means the same as the word sunat in Malay and Banjarese. The word sunat in Javanese means khitan (Mangunsuwito, 2009, p.531).

Buluh has another name in Banjarese, that is paring, (h)aur, and walang (Kawi, 2002, p.312). $B u l u h$ in the Indonesia language known as bambu. On the seasion of flyng kites, buluh is often used to make kites. Buluh is a bambu atau aur (Departemen Pendidikan Nasional, 2008, p.221). Burung bubut as Banjarese vocabulary supported statement by Kawi (2002, p.44) which said that bubut is sejenis burung. Burung bubut is a type of bird. The word burung is derived from the Malay vocabulary, namely buruy (Adelaar, 1994, p.53). Zoetmulder \& Robson (2006, p.136) stated that bubut is sebangsa burung (burung hantu kecil).

Blust (1985, p.50) stated that buruk vocabulary and buruk has the PAN, that is *buRuk which means busuk or lapuk. The word lipas in Malay and Banjarese means kecoa which is an Austronesian language family. It is evidenced by the explanation of Smith (2018, p.29) that the reconstruction of the PMP to lipas is *ipəs. Lipas is kecoa (Hapip, 2008, p.112). Blust (1985, p.168) stated that the word (h)ayit which means sangit (nasi atau sekoi) atau bau nasi atau sekoi yang hangus. The word limau is an Austronesian language family. According to Aman \& Latif (2012, p.61), said limau contained in the Malay vocabulary has PM *limau. Limau in Banjarese vocabulary is jeruk (orange) (Hapip, 2008, p. 109-110). Hapip (2008, p.109-110) detailing the types of limau as below.

Limau badalungga is a sour orange, oval form of the handheld. Limau Bali is Bali citrus. Limau keprok is keprok citrus. Limau kuit is citrus sambal (whose skin resembled citrus but big yummy smelling). Limau nipis is lemon. Limau purut is a purut citrus. Limau sambal is sambal citrus. 
The word merungut after traceability is also found in old Javanese. In the old Javanese language, a

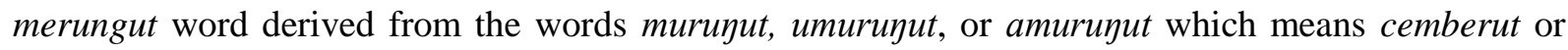
ganas (Zoetmulder \& Robson, 2006, p.683). Poerwadarminta (1948, p.126) stated that mrengoet (scowled) exists in Javanese which means Masam mukanya. The word umbut, tumbung, sabut, tempurung is part of the coconut palm. Coconut (Cocos nucifera) according to Blust (2013, p.5) is a tree that grows in the world of Austronesian. Humbut in old Javanese means taruk atau pucuk muda atau umbut (Zoetmulder \& Robson, 2006, p.369). Upih word was also in old Javanese. Upih word in old Javanese is upih, kelopak daun jenis palma (digunakan untuk membuat pembungkus yang tahan air (Zoetmulder \& Robson, 2006, p.1346). In Banjarese there is a proverb Mayang mamadahi upih, the meaning is young advised the older, something unusual (Hapip, 2008, p.201).

The word ular sawe or ular sawa in Malay and Banjarese vocabulary is an Austronesian language. It was reinforced by the opinions of Blust (2013, p.7) stated that the reconstruction of PAN for python is *sawa. *Sawa is a generic term for ular. Blust (2005, p.238) stated that (snake) sawa is the Malay vocabulary with PMP *sawa. The Blust views are based on Coolsma (1930) and Nothofer (1975, p.296ff). Therefore, Nothofer (2009, p.35) stated sawa is a large snake with MPBP *sawa. Nothofer (2009, p.35) stated that sawa in Malay equals sanca in the Sunda language. According to Nothofer (2009, p.35), sanca is sejenis ular sawa. In the dictionary of old Javanese Indonesia by Zoetmulder \& Robson (2006, p.1058) found the word sawa or ula sawa that means ular sanca or python. Blust (1984-1985, p.63) has lexical reconstruction nonsea fauna including python. Lexical reconstruction results for python were sawa. It is also (m)-asam (acid) word stated by Blust (1985, p.168) as a vocabulary of Malay vocabulary. In addition, Blust (1985, p.128) stated that janggut (jangut) is a vocabulary of Malay which means rambut yang tumbuh di dagu (Manusia).

For luruh word and gugur word mean jatuh. Kawi (2002, p.129) explained that the word luruh and gugur have proto is PM * jatuh. Kawi (2002, p.129) also stated that the words luruh from PMLS *ruru. Kawi $(2002$, p.129) stated that the gugur is a common word and luruh is a special word. The word jeruk in Malay or jaruk in Banjar are Austronesian languages family. It can be known from research results Kawi, Durasid, \& Effendi (1993, p.74) that the word jaruk has reconstruction etimon PAN d'a!uk. Hapip (2008, p.68) stated that jaruk are asinan. Hapip (2008, p.68) mentioned jaruk dami, jaruk tigaron, jaruk ramania, jaruk bawang basihung, intalu jaruk, dan jaruk balimbing tunjuk. Hapip (2008, p.68) described the type of jaruk as below.

Jaruk dami is salted jackfruit fiber. Jaruk tigaron salted tigaron flowers. Jaruk ramania is a salted fruit gandaria. Jaruk basihung is salted food from garlic. Intalu jaruk is salted egg. Jaruk balimbing tunjuk is salted star fruit (tamarind).

Ikan buntal word is a Malay vocabulary (Adelaar, 1994, p.55). Adelaar (1994, p.55; Adelaar in Bellwood, Fox, \& Tryon (eds., 2006, p. 84) stated that the ikan buntal is ikan kotak (kurungan), ikan bulat/bundar seperti bola. In old Javanese, ikan buntal was named buntěk. Ikan buntěk is a fish round or marine fish that can inflate its body (Zoetmulder \& Robson, 2006, p.142).

\section{Conclusions}

Research to find the equation of Malay vocabulary In the animation series of Upin and Ipin with Banjarese vocabulary in South Kalimantan concluded that there is some vocabulary equation in terms of writing, pronunciation, and meaning. Based on the results of the analysis and discussion above, could be concluded that the Malay vocabulary in the animation series of Upin and Ipin has an equation of form and meaning with the Banjarese vocabulary in South Kalimantan. This research also found there was a semblance of form and meaning between the Malay vocabulary in the animation series of Upin and Ipin with Banjarese vocabulary in South Kalimantan. Besides, there is some vocabulary in 
the same form but different meaning between Malay vocabulary in the animation series of Upin and Ipin with Banjarese vocabulary in South Kalimantan.

\section{Acknowledgment}

The researcher says sincere thanks to Prof. H. Sutarto Hadi, M.Si., M.Sc., Ph.D. as the Rector of the Lambung Mangkurat University, which has provided assistance and support for the research and writing of this scientific article. Scientific articles are the result of research funded by DIPA PNBP Master's degree of Indonesian Language and Literature Education Program, FKIP, Lambung Mangkurat University 2018.

\section{Ethics Committee Approval}

The author confirms that the study does not need ethics committee approval according to the research integrity rules in their country (Date of Confirmation: 5.3.2021).

\section{References}

Adelaar, K. A. (1984). Some Proto-Malayic Affixes.In: Bijdragen tot de Taal-, Land- en Volkenkunde 140 (1984), no: 4, Leiden, 402-421.

Adelaar, K. A. (1985). Proto Malayic. Aglasserdam: Offsetdrukkerij Kanters.

Adelaar, K. A. (1994). Malay and Javanese Loanwords in Malagasy, Tagalog and Siraya (Formosa). In: Bijdragen tot de Taal-, Land- en Volkenkunde 150 (1994), no: 1, Leiden, 50-65.

Adelaar, K. A. (2004). Where does Malay come from? Twenty years of discussions about homeland, migrations and classifications. Bijdragen tot de Taal-, Land-en Volkenkunde (BKI) 160-1 (2004): $1-30$.

Adelaar, K. A. (2006). Chapter 4. Borneo as a Cross-Roads for Comparative Austronesian Linguistics. In Bellwood, Peter; Fox, James J.; and Tryon, Darrell (Eds.). The Austronesians, Historical and comparative perspectives. Canberra ACT Australia: The Department of Anthropology as Part of The Comparative Austronesian Project, Research School of Pacific Studies The Australian National University.

Aitkuzhinova-Arslan, A., Gün, S., \& Üstünel, E. (2016). Teaching vocabulary to Turkish young learners in semantically related and semantically unrelated sets by using digital storytelling. Journal of Language and Linguistic Studies, 12(1), 42-54.

Akbulut, D. F. (2017). Effects of Morphological Awareness on Second Language Vocabulary Knowledge. Journal of Language and Linguistic Studies, 13(1), 10-26.

Aman, R.\& Latif, M. N. (2012). Pembuktian dan Pengukuhan Teori The New Malay Homeland Berdasarkan Rekonstruksi dan Klasifikasi Bahasa Iban Purba Sarawak. CREAM - Current Research in Malaysia, 1(1), October 2012: 51-72.

Arlena, W. M.\& Kurniasari, N. G. A. K. (2013). Malays, China, and Indian Ethnicities (Case Study: Art and Ethnography Content Analysis, Multiculturalism on Upin Ipin Animation). Jurnal Komunikasi ASPIKOM, 2(1), Juli, hlm. 629-639.

Aziz, Z. A.; Yusuf, Y. Q.; Nasir, C.; \& Masyithah, C. (2017). Cross-Linguistic Influences of Malay Through Cartoons on Indonesian Children's Language Use in the Home Domain. Indonesian Journal of Applied Linguistics, 7(2), September 2017, pp. 339-348. 
Blust, R. (1984-1985). The Austronesian Homeland: A linguistic perspective. Asian Perspectives, XXVI (1): 45-67.

Blust, R. A. (1985). Telaah Komparatif Bahasa Nusantara Barat: Kumpulan Karya R. A. Blust. Purwo, Bambang Kaswanti dan Collins, James T. (Eds.). Jakarta: Djambatan.

Blust, R. A. (1988). Malay Historical Linguistics: A Progress Report. Dalam Rekonstruksi dan Cabang-Cabang Bahasa Melayu Induk. Kuala Lumpur: Dewan Bahasa dan Pustaka.

Blust, R. A. (2005). Must sound change be linguistically motivated?*Diachronica, 22 (2): 219-269.

Blust, R. A. (2013). The Austronesian languages. Canberra, Australia: Asia-Pacific Linguistics Research School of Pacific and Asian Studies The Australian National University.

Cense, A. A. \& Uhlenbeck, E. M. (1958). Critical Survey of Studies on the Languages of Borneo. 'SGravenhage: Martinus Nijhoff.

Coolsma, S. 1930 [1884]. 2nd ed. Soendaneesch-Hollandsch Woordenboek. Leiden: A. W. Sijthoff.

de Hollander, J. J. (1984). Pedoman Bahasa dan Sastra Melayu. Terjemahan oleh T. W. Kamil. Jakarta: Balai Pustaka.

Departemen Pendidikan Nasional. (2008). Kamus Besar Bahasa Indonesia Pusat Bahasa Edisi Keempat. Jakarta: PT. Gramedia Pustaka Utama.

Durasid, D.\& Kawi, Dj. (1978). Bahasa Banjar Hulu. Jakarta: Pusat Pembinaan dan Pengembangan Bahasa, Departemen Pendidikan dan Kebudayaan.

Hapip, A. Dj.; Kawi, Dj.; \& Noor, B. (1981). Struktur Bahasa Banjar Kuala. Jakarta: Pusat Pembinaan dan Pengembangan Bahasa, Departemen Pendidikan dan Kebudayaan.

Hapip, A. Dj. (2008). Kamus Banjar Indonesia. Banjarmasin: CV Rahmat Hafiz Al Mubaraq.

http://ms.upinipin.wikia.com/wiki/Fail:0814_kelapa_tua.pngaccessed 15 Juli 2018.

http://ms.upinipin.wikia.com/wiki/Fail:0814_tumbung_kelapa.pngaccessed 14 Juli 2018.

http://ms.upinipin.wikia.com/wiki/Fail:0814_umbut_kelapa.pngaccessed 15 Juli 2018.

http://www.dzargon.com/2016/05/apasih-perbedaan-antara-buah-duku-langsat-kokosan.html accessed 15 Agustus 2017.

https://id.wikipedia.org/wiki/Ikan_buntal accessed 24 April 2018.

https://id.wikipedia.org/wiki/Kecoa accessed 7 Mei 2018.

https://id.wikipedia.org/wiki/Upin_\%26_Ipinaccessed 29 Juli 2017.

https://ms.wikipedia.org/wiki/Ikan_Keliaccessed 21 Juli 2018.

https://ms.wikipedia.org/wiki/Lebah_kelulut accessed 4 Juli 2018.

https://www.wattpad.com/471396352-upin-ipin-musim-6accessed 15 Juli 2018.

https://www.youtube.com/watch?v=k-Fcq9s3nuYaccessed 15 Juli 2018.

Ikram, A.; Saleh, S.; Mutiara, P. M.; Augusdin, J.; \& Rukmi, M. I. (1985). Kamus Melayu-Indonesia. Jakarta: Pusat Pembinaan dan Pengembangan Bahasa, Departemen Pendidikan dan Kebudayaan.

Kawi, Dj.; Durasid, D.; \& Effendi, R. (1993). Refleksi Etimon Proto Austronesia dalam Bahasa

Banjar. Jakarta: Pusat Pembinaan dan Pengembangan Bahasa, Departemen Pendidikan dan Kebudayaan. 
Kawi, Dj. (2002). Bahasa Banjar, Dialek dan Subdialeknya. Banjarmasin: PT. Grafika Wangi Kalimantan.

Kawi, Dj. (2011). Telaah Bahasa Banjar. Banjarbaru: Scripta Cendekia.

Keraf, G. (1991). Linguistik Bandingan Historis. Jakarta: PT Gramedia Pustaka Utama.

Lubis, H. I.; Sulaiman, H. A.; Umar, H. S. M.; Sinaga, M.; \& Shanty, I. L. (1993). Tata bahasa Melayu Riau. Jakarta: Pusat Pembinaan dan Pengembangan Bahasa, Departemen Pendidikan dan Kebudayaan.

Mahsun. (2014). Genolinguistik, Kolaborasi Linguistik dengan Genetika dalam Pengelompokan Bahasa dan Populasi Penuturnya. Yogyakarta: Pustaka Pelajar.

Mangunsuwito, S.A. (2009). Kamus Lengkap Bahasa Jawa, Jawa-Jawa, Jawa-Indonesia, IndonesiaJawa. Bandung: Yrama Widya.

Nothofer, B. (1975). The Reconstruction of Proto-Malayo-Javanic. (= Verhandelingen van het Koninklijk Instituut voor Taal-, Land- en Volkenkunde, 73.) The Hague: Nijhoff.

Nothofer, B. (2009). Patut dan Turut; Dua dan Separuh; Datar dan Rata: Kata Warisan atau Kata Pinjaman? Catatan Mengenai Etimologi Kosakata Melayu. Linguistik Indonesia, Jurnal Ilmiah Masyarakat Linguistik Indonesia, 27(1): 23-43.

Poerwadarminta, W. J. S. (1948). Baoesastra Djawi-Indonesia. Djakarta: Balé Pustaka.

Rafiek, M. (2010). Masa Depan Bahasa Banjar. Makalah disampaikan dalam Kongres Kebudayaan Banjar II pada tanggal 4 s.d. 7 April. Banjarmasin: Pemerintah Provinsi Kalimantan Selatan.

Rusieshvili-Cartledge, M. \& Gözpınar, H. (2014). Similar and unique in the family: How to raise children (Using examples of Turkish and Georgian proverbs relating to children). Journal of Language and Linguistic Studies, 10(1), 67-77.

Saputro, M. E. (2011). Upin \& Ipin: Melayu Islam, Politik Kultur, dan Dekomodifikasi New Media. Kontekstualita, 26(1), hlm. 39-69.

Smith, A. D. (2018). The Barito Linkage Hypothesis, with A Note on The Position of Basap. Journal of the Southeast Asian Linguistics Society (JSEALS), 11(1) (2018): 13-34.

Zoetmulder, P. J. \& Robson, S. O. (2006). Kamus Jawa Kuna Indonesia. Terjemahan oleh Darusuprapta dan Sumarti Suprayitna. Jakarta: PT Gramedia Pustaka Utama.

\section{AUTHOR BIODATA}

Muhammad Rafiek is a lecturer in the S1 and S2 Indonesian Language and Literature Education Program, Teacher Training and Education Faculty, Lambung Mangkurat University, Banjarmasin, Indonesia. M. Rafiek is a doctor who graduated from the Indonesian Language Education S3 Program in Malang State University in 2010. His research interest is Hikayat Raja Banjar, Banjarese, Madihin, and Child Language. 